\title{
Arctic (palaeo) river discharge and environmental change: evidence from the Holocene Kara Sea sedimentary record
}

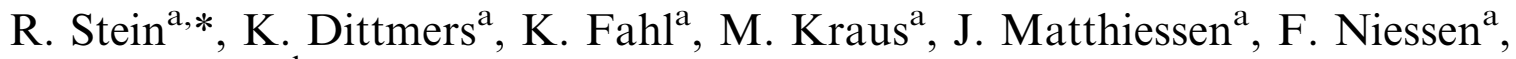 \\ M. Pirrung ${ }^{b}$, Ye. Polyakova ${ }^{c}$, F. Schoster ${ }^{\mathrm{a}}$, T. Steinke ${ }^{\mathrm{a}}$, D.K. Fütterer ${ }^{\mathrm{a}}$ \\ a Alfred Wegener Institute for Polar and Marine Research, Columbusstrasse, Bremerhaven 27568, Germany \\ ${ }^{\mathrm{b}}$ Institut für Geowissenschaften, Friedrich-Schiller-Universität, Jena, Germany \\ ${ }^{\mathrm{c}}$ Moscow State University, Moscow, Russia
}

\begin{abstract}
In this paper, we summarize data on terrigenous sediment supply in the Kara Sea and its accumulation and spatial and temporal variability during Holocene times. Sedimentological, organic-geochemical, and micropaleontological proxies determined in surface sediments allow to characterize the modern (riverine) terrigenous sediment input. AMS- ${ }^{14} \mathrm{C}$ dated sediment cores from the $\mathrm{Ob}$ and Yenisei estuaries and the adjacent inner Kara Sea were investigated to determine the terrigenous sediment fluxes and their relationship to paleoenvironmental changes. The variability of sediment fluxes during Holocene times is related to the post-glacial sea-level rise and changes in river discharge and coastal erosion input. Whereas during the late/middle Holocene most of the terrigenous sediments were deposited in the estuaries and the areas directly off the estuaries, huge amounts of sediments accumulated on the Kara Sea shelf farther north during the early Holocene before about 9 Cal. kyr BP. The maximum accumulation at that time is related to the lowered sea level, increased coastal erosion, and increased river discharge. Based on sediment thickness charts, echograph profiles and sediment core data, we estimate an average Holocene (0-11 Cal. kyr BP) annual accumulation of $194 \times 10^{6} \mathrm{t} \mathrm{yr}^{-1}$ of total sediment for the whole Kara Sea. Based on late Holocene (modern) sediment accumulation in the estuaries, probably $12 \times 10^{6} \mathrm{tyr}^{-1}$ of riverine suspended matter (i.e., about $30 \%$ of the input) may escape the marginal filter on a geological time scale and is transported onto the open Kara Sea shelf. The high-resolution magnetic susceptibility record of a Yenisei core suggests a short-term variability in Siberian climate and river discharge on a frequency of 300-700 yr. This variability may reflect natural cyclic climate variations to be seen in context with the interannual and interdecadal environmental changes recorded in the High Northern Latitudes over the last decades, such as the NAO/AO pattern. A major decrease in MS values starting near 2.5 Cal. kyr BP, being more pronounced during the last about $2 \mathrm{Cal}$. kyr BP, correlates with a cooling trend over Greenland as indicated in the GISP-2 Ice Core, extended sea-ice cover in the North Atlantic, and advances of glaciers in western Norway. Our still preliminary interpretation of the MS variability has to be proven by further MS records from additional cores as well as other highresolution multi-proxy Arctic climate records.

(C) 2003 Elsevier Ltd. All rights reserved.
\end{abstract}

\section{Introduction and background}

The present state of the Arctic Ocean strongly depends on the large river discharge. Today, the annual freshwater inflow by major Arctic rivers reaches a total of $3300 \mathrm{~km}^{3}$ which is eqivalent to $10 \%$ of the global runoff (Aagaard and Carmack, 1989). Of particular importance is the Kara Sea (Fig. 1), the third largest Arctic marginal sea with an area of about $900,000 \mathrm{~km}^{2}$, receiving about $50 \%\left(1480 \mathrm{~km}^{3} \mathrm{yr}^{-1}\right)$ of the total river

*Corresponding author. Tel.: +49-471-4831-1576; fax: +49-4714831-1580.

E-mail address: rstein@awi-bremerhaven.de (R. Stein). run-off discharged to the entire Eurasian Arctic (Gordeev et al., 1996; Holmes et al., 2002; Peterson et al., 2002; Rachold et al., 2003). Most of this discharge is related to the major rivers $\mathrm{Ob}$ and Yenisei contributing 404 and $620 \mathrm{~km}^{3} \mathrm{yr}^{-1}$, respectively (Table 1). The discharge exhibits strong seasonal and interannual variations (Pavlov and Pfirman, 1995; Gordeev et al., 1996; Holmes et al., 2002). The maximum discharge rate is observed in June, when about $45-65 \%$ of the annual freshwater run-off and $80 \%$ of the annual suspended matter are released (Shiklomanov and Skakalsky, 1994; Gordeev et al., 1996).

The Arctic rivers also transport large amounts of dissolved and suspended material (i.e., chemical elements, 


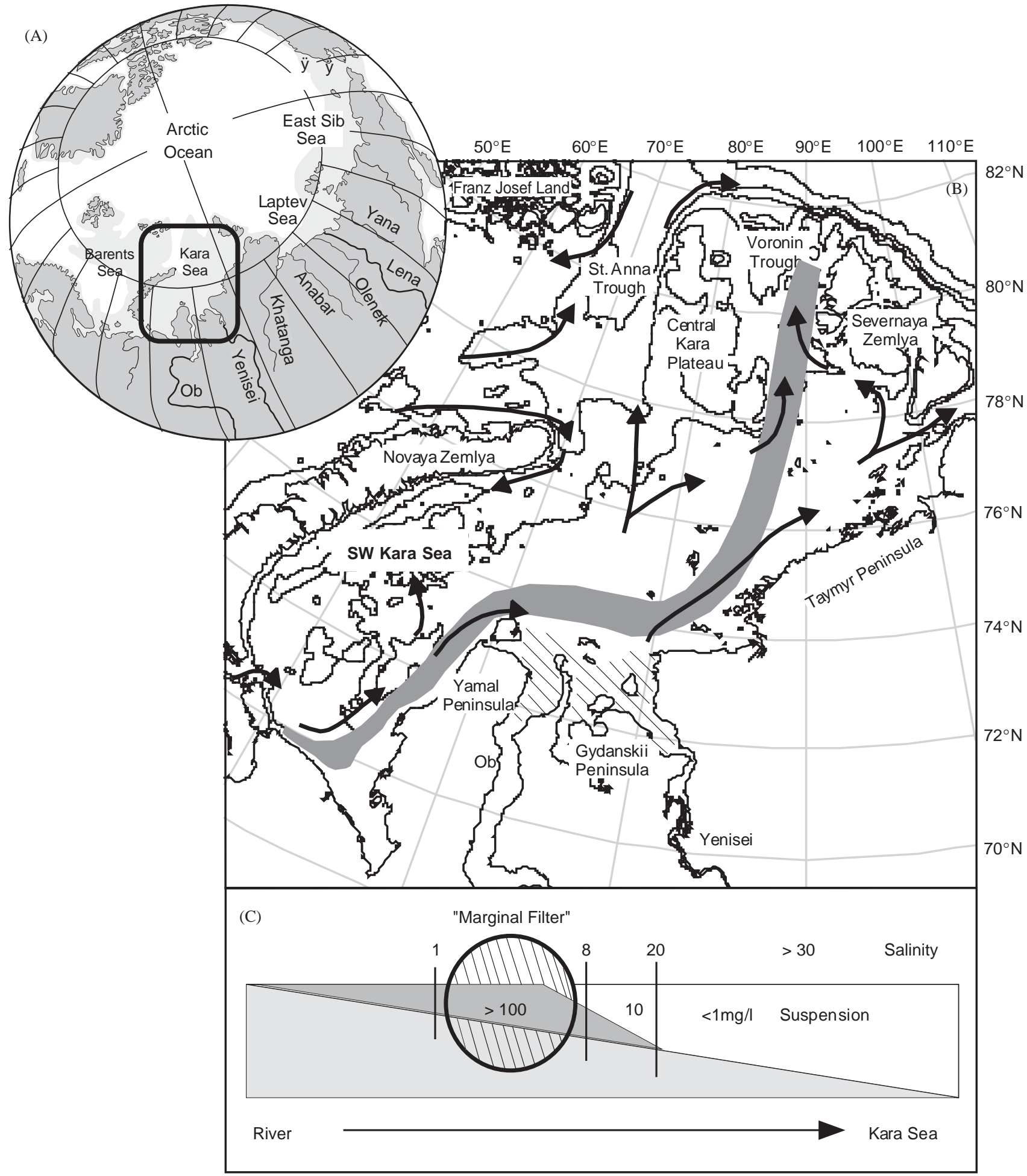

Fig. 1. Overview map of northern Eurasia and the adjacent Arctic Ocean indicating the major Eurasian rivers draining into the Arctic Ocean. The study area of the Kara Sea is marked. Map of the Kara Sea showing the surface-water circulation pattern during autmn/winter (Harms et al., 2000) and the distribution of polynyas (Pavlov and Pfirman, 1995). The area of the marginal filter is indicated as hatched field. The SW Kara Sea (i.e., west of $68^{\circ} \mathrm{E}$ ) is not included in our own study (see discussion). Scheme of the marginal filter (according to Lisitzin, 1995).

siliciclastic and organic matter) towards the ocean (Table 1; Gordeev et al., 1996; Rachold et al., 2003). The modern discharge of total suspended matter by the $\mathrm{Ob}$ and Yenisei rivers is $15.5 \times 10^{6}$ and $4.7 \times 10^{6} \mathrm{tyr}^{-1}$, respectively. The particulate organic carbon supply by the same rivers is estimated to reach about $0.36 \times 10^{6}$ and $0.17 \times 10^{6} \mathrm{tyr}^{-1}$, respectively. For the Yenisei, a total suspended matter supply of $14.4 \times 10^{6} \mathrm{t} \mathrm{yr}^{-1}$, which 
Table 1

Modern annual input of total suspended matter (TSM) and particulate terrigenous organic matter (POC) in the Kara Sea (data from Rachold et al., 2003)

\begin{tabular}{|c|c|c|c|c|c|}
\hline Kara Sea & $\begin{array}{l}\text { Water discharge } \\
\left(\mathrm{km}^{3} \mathrm{yr}^{-1}\right)\end{array}$ & $\operatorname{TSM}\left(\mathrm{mg}^{-1}\right)$ & $\operatorname{TSM}\left(10^{6} \mathrm{tyr}^{-1}\right)$ & $\mathrm{POC}\left(\mathrm{mg}^{-1}\right)$ & $\operatorname{POC}\left(10^{6} \mathrm{tyr}^{-1}\right)$ \\
\hline \multicolumn{6}{|l|}{ Terrigenous input (Rachold et al., 2003) } \\
\hline \multicolumn{6}{|l|}{ Rivers } \\
\hline $\mathrm{Ob}$ & 404 & 37 & 15.5 & 0.9 & 0.36 \\
\hline Yenisei & 620 & 8 & 4.7 & 0.3 & 0.17 \\
\hline Yenisei & & & $14.4^{\mathrm{a}}$ & & $0.5^{\mathrm{a}}$ \\
\hline Others & 456 & 20 & 10.7 & & $?$ \\
\hline Total & 1480 & & $40.6^{\mathrm{b}}$ & & $>0.9^{\mathrm{b}}$ \\
\hline Coastal erosion & & & $? 109(<55)$ & & $? 1(<0.4)$ \\
\hline Eolian & & & 0.55 & & 0.17 \\
\hline Total terrigenous input & & & $? 150(<96)$ & & $? 2.1(<1.5)$ \\
\hline \multicolumn{6}{|l|}{ Ocean currents } \\
\hline \multicolumn{6}{|l|}{ Net inflow from the Barents Sea } \\
\hline \multirow[t]{2}{*}{ Kara Strait } & $1240^{\mathrm{c}}$ & $2^{\mathrm{d}}$ & 2.5 & $0.036^{\mathrm{e}}$ & 0.05 \\
\hline & $(\max .18,600)^{\mathrm{c}}$ & & $(\max .37 .2)$ & & $(\max .0 .7)$ \\
\hline Franz Josef Land-Novaya Zemlya & $(\max .17,100)^{\mathrm{c}}$ & $3^{\mathrm{d}}$ & $(\max .51)$ & $0.029^{\mathrm{e}}$ & $\begin{array}{l}0.15-0.3 \\
(\max .0 .5)\end{array}$ \\
\hline \multicolumn{6}{|l|}{ Net outflow from the Kara Sea } \\
\hline Vilkitsky Strait & $4900-11,000^{\mathrm{c}}$ & $?$ & $?$ & $?$ & $?$ \\
\hline Arctic Ocean & $19,000-22,000^{\mathrm{c}}$ & $?$ & $?$ & $?$ & $?$ \\
\hline
\end{tabular}

For the Yenisei, input values for times preceding the dam constructed near Krasnoyarsk in 1967 are also given (data from Telang et al., 1991; Holmes et al., 2002). The coastal erosion values (Romankevich and Vetrov, 2001) are probably too high, and values reduced by $>50 \%$ are more realistic (numbers in brackets; see discussion in the text). In addition, net inflow of water masses from the Barents Sea via Kara Strait (Strait of Karskiye Vorota) into the southwestern Kara Sea and between Novaya Zemlya and Franz Josef Land into the northwestern Kara Sea as well as net outflow of water masses from the Kara Sea into the Arctic Ocean and through Vilkitsky Strait into the Laptev Sea are given (Pavlov and Pfirman, 1995). Using data from measurements of TSM (Medvedev and Potekhina, 1986) and POC (Romankevich et al., 2000) of the water masses in the southeastern and northeastern Barents Sea, TSM and POC input values were calculated.

${ }^{a}$ Measured value for times preceding the dam constructed near Krasnoyarsk (Telang et al., 1991; Holmes et al., 2002).

${ }^{\mathrm{b}}$ Using the Yenisei pre-dam value.

${ }^{\mathrm{c}}$ Pavlov and Pfirman (1995).

${ }^{\mathrm{d}}$ Medvedev and Potekhina (1986).

${ }^{\mathrm{e}}$ Romankevich et al. (2000).

is about three times higher than the modern value, has been measured for times preceding the dam constructed near Krasnoyarsk in 1967 (Table 1; Telang et al., 1991; Holmes et al., 2002). The input of particulate organic matter prior to the dam construction was probably also three times higher than today (i.e., about $\left.0.5 \times 10^{6} \mathrm{tyr}^{-1}\right)$. Using the Yenisei pre-dam values, this results in a total riverine input into the Kara Sea of about $41 \times 10^{6}$ and $1 \times 10^{6} \mathrm{tyr}^{-1}$ of total suspended matter and particulate organic carbon, respectively (Table 1). Besides river discharge, input by coastal erosion, winds, and ocean currents are further processes controlling the sediment input into the Kara Sea (Table 1).

Most of the riverine suspended matter is trapped in the estuaries where the river current velocity decreases, and where freshwater mixes with saltwater (salinities of about 2-10) and rapid accumulation (precipitation) of fine-grained suspension occurs due to flocculation/ aggregation processes (Fig. 1: Milliman, 1981; Lisitzin,
1995). Based on direct measurements of suspended matter in the water column, more than $90 \%$ of the suspended matter (including particulate organic carbon) accumulate within this so-called "marginal filter" (Lisitzin, 1995). This results in thick sequences of young (Holocene), soft sediments overlying the pre-Holocene basement in the $\mathrm{Ob}$ and Yenisei estuaries (Fig. 2; Stein et al., 2000; Dittmers et al., 2003). In the Yenisei area north of about $73^{\circ} 30^{\prime} \mathrm{N}$, the thickness of the Holocene sedimentary cover approaches zero (Fig. 2).

The fluvial fresh-water supply is essential for the maintainance of the ca $200 \mathrm{~m}$ thick low-salinity layer of the central Arctic Ocean and, thus, contributes significantly to the strong stratification of the near-surface water masses, encouraging sea-ice formation. The melting and freezing of sea ice result in distinct changes in surface albedo, energy balance, and biological and sedimentary processes. Significant amounts of sediments can be incorporated into the sea ice and subsequently exported from the shelf towards the open 


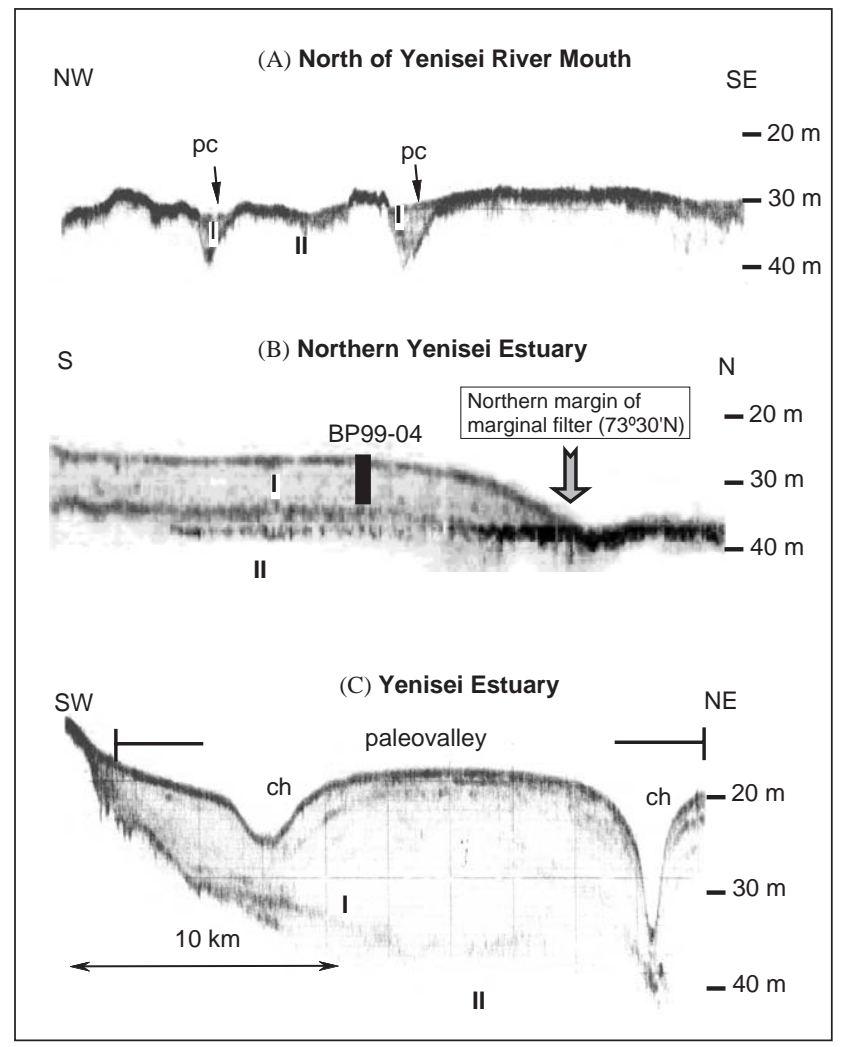

Fig. 2. Sediment echograph profiles $\mathrm{A}$ to $\mathrm{C}$ from the Yenisei area (Stein et al., 2000, 2003a, b; Dittmers et al., 2003). Profile A: North of Yenisei River mouth; profiles B and C: Yenisei Estuary. Roman numbers indicate acoustic Unit I (Holocene soft sediments) and Unit II (pre-Holocene "basement"). The location of sediment core BP99-04 and the northern margin of the marginal filter are indicated. Channels (ch) and paleochannels (pc) are shown. Numbers at the right side of the profiles indicate water depth in meters. For location of profiles see Fig. 3.

ocean (e.g., Pfirman et al., 1990; Nürnberg et al., 1994; Dethleff et al., 2000; Eicken et al., 2000). Another important aspect related to sea ice and sediment transport is the fact that freezing of sea water results in brine formation. The dense saline water may flow through submarine channels and move resuspended matter in the bottom nepheloid layer towards the outer shelf, across the shelf break, and into the Arctic basins (Lisitzin, 1995). With this process, which is mainly active during the autumn to winter period, sediments as well as organic matter may escape the marginal filter.

Freshwater and sea ice are exported from the Arctic Ocean through Fram Strait into the North Atlantic. Changes in these export rates of fresh-water would result in changes of North Atlantic as well as global oceanic circulation patterns. The interplay of the cold Arctic freshwater-rich surface layer and its ice cover with the relatively warm and saline Atlantic water is important for the renewal of deep waters driving the global thermohaline circulation ("Global Conveyor Belt"; Broecker, 1997). Oceanic variations, such as the
"Great Salinity Anomaly" (Dickson et al., 1988) which was observed during the 1970s in the North Atlantic, could possibly result from a variation of Arctic Ocean freshwater supply (Aagaard and Carmack, 1989).

A significant increase in Siberian river discharge (see Section 4, Fig. 18), associated with a warmer climate and enhanced precipitation in the river basins, has been observed during the past decades (Semiletov et al., 2000; Serreze et al., 2000; Peterson et al., 2002). Contemporaneously, an increase in the amount and temperature of Atlantic Water inflow into the Arctic, a reduced sea-ice cover, a thawing of permafrost and a retreat of small Arctic glaciers are obvious (Dickson et al., 2000; Serreze et al., 2000). All these environmental changes seem to be related to a cyclic variation of the Northern Hemisphere/Arctic atmospheric circulation pattern, i.e., the "Arctic Oscillation (AO)" and the "North Atlantic Oscillation (NAO)" (Hurrell, 1995; Thompson and Wallace, 1998; Dickson et al., 2000). During a positive $\mathrm{NAO} / \mathrm{AO}$ Index phase, warm wet air is brought to Northern Europe and the Russian Arctic, causing increased precipitation in the drainage area of the Siberian rivers, which result in increased river discharge to the Arctic Ocean. Details about the interaction between $\mathrm{NAO} / \mathrm{AO}$ and climate change, however, are still under discussion.

Having in mind the importance of river discharge (see also Stein, 1998, 2000), a Russian-German research project on "Siberian River Run-off (SIRRO)" was initiated to study in detail the freshwater discharge, its influence on biological, geochemical, and geological processes in the Kara Sea, and its variability in space and time (Stein et al., 2003b and further references therein). Here, we present new results of sedimentological and organic-geochemical studies performed on surface sediments and well-dated sediment cores from the southern Kara Sea and $\mathrm{Ob}$ and Yenisei estuaries. The main goals of this synthesis paper are:

- to characterize surface sediments in respect to modern river discharge;

- to interpret the sediment core records in respect to post-glacial sea-level rise and changes in Holocene river discharge;

- to calculate a Holocene total sediment budget; and

- to study the short-term variability in Holocene river discharge.

\section{Material and methods}

Within SIRRO, five expeditions with RV "Akademik Boris Petrov" were carried out in 1997, 1999, 2000, 2001, and 2002, and a large number of surface sediment samples as well as long sediment cores were obtained for multidisciplinary studies (Fig. 3; Matthiessen and 


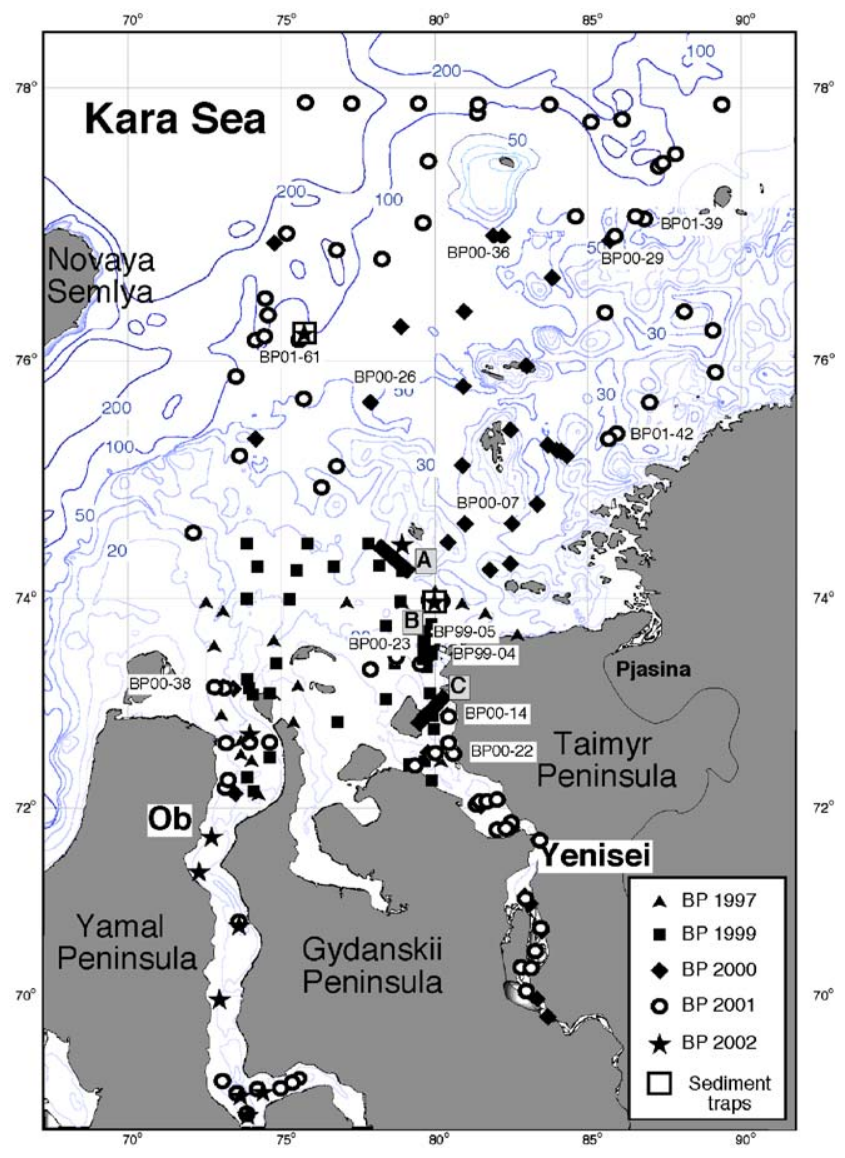

Fig. 3. Station map of "Akademik Boris Petrov" expeditions BP 1997, 1999, 2000, 2001, and 2002. Location of sediment cores discussed in this paper are shown (see Figs. 12 and 15) as well as the location of the acoustic profiles of Fig. 2 (black bars A-C).

Stepanets, 1998; Stein and Stepanets, 2000, 2001, 2002; Schoster and Levitan, 2003). Correlation of sediment coring sites as well as identification of structure and thickness of near-surface sediments were performed by acoustic profiling. A survey of more than $10,000 \mathrm{~km}$ of profiles in total offers detailed information about the seafloor topography and the thickness and structure of the upper Quaternary sediment cover of the Kara Sea. Furthermore, it offers a suitable base to achieve a postglacial sediment budget. For the subbottom profiling, the hull-mounted ELAC system of RV "Akademik Boris Petrov" (ELAC echograph LAZ 72, HoneywellNautik, Kiel, Germany) was used, which operates at $12 \mathrm{kHz}$. In 2001 we amplified and plotted the ELAC signal using a GeoAccoustics receiver and Ultra printer 120, respectively (Stein and Stepanets, 2002).

Within this study, various proxies were used to characterize the sediment composition and its interpretation in relationship to river discharge: magnetic susceptibility (MS), grain-size distribution, clay-mineral composition, organic carbon data, and palynomorph and diatom abundances.

\subsection{Physical properties}

Whole-core physical properties were measured in $1 \mathrm{~cm}$ depth intervals using a Geotek Multi Sensor Core Logger. The system provides data of density, P-wave velocity and MS (e.g., Schultheiss and Mienert, 1987; Schultheiss and McPhail, 1989; Weaver and Schultheiss, 1990). Changes in these parameters reflect changes in porosity and/or sediment composition (Thompson and Oldfield, 1986; Weber et al., 1997). The technical setup of the logging system, as used during "Akademik Boris Petrov" expedition in 2001, is described in Stein and Stepanets (2002). For the determination of MS of surface samples, freeze-dried samples were densely packed in $12.5 \mathrm{~cm}^{3}$ plastic vials and measured using a MS2B sensor, Bartington Ltd, UK (for further information see Niessen and Weiel, 1996). Because the studied sediment cores exhibit a strong gradient in porosity and because MS of water is nearly zero, in high porosity intervals the MS signal carried by the minerals would be underestimated. Thus, a porosity correction was carried out according to Niessen et al. (1998). This enables estimates of amounts of MS carrier grains, independently of the porosity.

Because ferrimagnetic minerals have a significantly higher susceptibility $\left(k=+10^{-2}\right)$ than most other common minerals $\left(-10^{-6}\right.$ to $\left.+10^{-6}\right)$, changes in susceptibility are normally controlled by variations in the content of ferrimagnetic matter (mostly magnetite, titanomagnetite or maghemite; Thompson and Oldfield, 1986). Volcanic rocks contain significantly higher amounts of ferrimagnetic minerals than other rock types. Consequently, MS can be used to distinguish between different source areas of terrigenous sediments.

\subsection{Grain size and clay minerals}

For disaggregation and removal of organic matter bulk sediment samples were shaken in a solution of hydrogen peroxide $(10 \%)$. Coarse fraction $>63 \mu \mathrm{m}$ was separated by wet sieving. Silt $(2-63 \mu \mathrm{m})$ and clay $(<2 \mu \mathrm{m})$ fractions were divided by a Stoke's law settling. To calculate the grain-size distribution all fractions were weighted after drying.

The clay fraction $<2 \mu \mathrm{m}$ was used for X-ray diffraction (XRD) analysis. As an internal standard $1 \mathrm{ml}$ of a $0.4 \%$ molybdenite suspension was added to a $40 \mathrm{mg}$ clay sample. This mixture was dispersed and sucked onto a membrane filter (pore diameter $0.15 \mu \mathrm{m}$ ) by vacuum filtration to get high orientation of the clay minerals. After vaporisation with ethyleneglycol for about $24 \mathrm{~h}$ at $50^{\circ} \mathrm{C}$ the samples were measured between $2-40^{\circ} 2 \theta$ with a step size of $0.02^{\circ} 2 \theta / \mathrm{s}$ and between 28 and $30.5^{\circ} 2 \theta$ with a step size of $0.005^{\circ} 2 \theta / \mathrm{s}$. The measurements were carried out with a Philips goniometer (PW1820) equipped with an automatic 
divergence slit, using $\mathrm{Co} \mathrm{K} \alpha$ radiation $(40 \mathrm{kV}, 40 \mathrm{~mA})$. The following peaks were used to identify clay minerals: $17 \AA$ for smectite, 10 and $5 \AA$ for illite, and $7 \AA$ for kaolinite plus chlorite. To differentiate kaolinite and chlorite we used intensity ratios of the $3.58 \AA$-kaolinite peak and the $3.54 \AA$-chlorite peak, identified by slow scan. Relative clay-mineral contents were calculated by using empirical factors after Biscaye (1965).

\subsection{Total organic carbon and n-alkanes}

Total organic carbon (TOC) and total nitrogen were measured by a LECO-CNS Analyser. The precision of this method is $0.05 \%$ for carbon and $0.005 \%$ for nitrogen. $\mathrm{C} / \mathrm{N}$-ratios (i.e., TOC/total nitrogen ratios) were calculated on a molar basis. For the lipid analyses the samples were extracted first with methanol, in a second step with dichloromethane:methanol $(1 / 1$ by vol.), and finally with dichloromethane. The total extract was transesterified using $3 \mathrm{~N}$ methanolic $\mathrm{HCl}$ $\left(50^{\circ} \mathrm{C}\right.$ for $\left.12 \mathrm{~h}\right)$ and separated in fractions by column chromatography. All components were analysed with a Hewlett Packard gas chromatograph (HP 6890, column $30 \mathrm{~m} \times 0.25 \mathrm{~mm}$; film thickness $0.25 \mu \mathrm{m}$; liquid phase: DB-5MS) using a temperature program as follows: $60^{\circ} \mathrm{C}$ ( $2 \mathrm{~min}$ ), $150^{\circ} \mathrm{C}$ (rate: $15^{\circ} \mathrm{C} \mathrm{min}^{-1}$ ), $320^{\circ} \mathrm{C}$ (rate: $3^{\circ} \mathrm{min}^{-1}$; $20 \mathrm{~min}$ isothermal). The injection volume was $1 \mu \mathrm{l}$ using a cold injection system (temperature program: $60^{\circ} \mathrm{C}$ $(0.1 \mathrm{~min}), 320^{\circ} \mathrm{C}$ (rate: $\left.12^{\circ} \mathrm{C} \mathrm{s}^{-1}, 60 \mathrm{~s}\right)$. Helium was used as carrier gas $\left(1.5 \mathrm{ml} \mathrm{min}^{-1}\right)$. The identification of the $n$-alkanes was carried out on the basis of GC retention time. For quantification, an internal standard (squalane) was added before any analytical step. Further details about the method are described in Fahl and Stein (1997, 1999) and Fahl et al. (2003).

\subsection{Palynomorphs}

The laboratory processing follows standard palynological procedures without using acetolysis (e.g. Rochon et al., 1999). After freeze-drying, samples were treated with cold hydrochloric $(10 \%)$ and hydrofluoric acids $(38-40 \%)$ to dissolve carbonates and silicates. Most of the fine organic matter was removed by wet sieving to enrich the particulate organic matter (POM) larger than $6 \mu \mathrm{m}$. Lycopodium spore tablets were added to calculate palynomorph concentrations (Stockmarr, 1971). Palynomorphs were identified and counted under a lightmicroscope (Fa. ZEISS) using $\times 400$ and $\times 1000$ magnification. For further details we refer to Matthiessen et al. (2000).

\subsection{Diatoms}

Diatoms were concentrated by treatment with $10 \%$ $\mathrm{HCl}$, and with $30 \% \mathrm{H}_{2} \mathrm{O}_{2}$, with subsequent decantation with distilled water. Subsequently the residues were mounted on glass slides with the medium Naphrax, which has a refraction index of 1.68. The diatom valves were examined under a light microscope at $\times 1000$ magnification. Generally, about 300-400 specimens were counted in each sample, and their abundances were converted to percent and number of val-ves per gram of dry sediment. For further details see Polyakova (2003).

\subsection{Chronology}

For reconstruction of paleoenvironment from sediment core records, a sufficient chronology is needed. Our chronology is primarily based on $\mathrm{AMS}^{14} \mathrm{C}$ datings of bivalves (Stein et al., 2003a). The $\mathrm{AMS}^{14} \mathrm{C}$ dates are $\delta^{13} \mathrm{C}$-normalized and corrected for a reservoir age of 440 years (Mangerud and Gulliksen, 1975). Calendar years were calculated according to Stuiver et al. (1998). Based on this chronological framework, age-depth diagrams were produced, and linear sedimentation and accumulation rates were calculated. Furthermore, the age-depth relationships were the basis for the transformation of the depth scales into age scales (for details see Stein et al., 2003a). Sediment core data and echosounding profiling data were the basis for calculation of sedimentary budgets.

\section{Results}

\subsection{Characteristics of surface sediments}

\subsubsection{Grain-size distribution}

In the southern study area, samples with high sand contents are mainly restricted to coastal areas of the northeastern Yenisei Estuary and the shallow shelf areas (Fig. 4). In the northern area with water depths $>50 \mathrm{~m}$, some samples also display high sand contents, probably representing relict sediments of Pleistocene age deposited at times of lowered sea level. Samples from the $\mathrm{Ob}$ and Yenisei estuaries, i.e., from the marginal filter area, mainly consist of clayey silt ( $40-60 \%$ silt, $30-40 \%$ clay; Steinke, 2002). In morphological depressions towards the north and, especially, towards the northeast, silty clay is predominant ( $>50 \%$ clay fraction) (Fig. 4 ).

\subsubsection{Clay mineral composition}

Smectite and illite are the dominant clay minerals in the investigated surface sediment samples, together reaching up to $75 \%$ of the clay minerals. Smectite values vary between about $30 \%$ and almost $60 \%$. Maximum smectite values $>50 \%$ were determined in the Yenisei Estuary and parts of the southern Kara Sea (Fig. 5a). In the Ob Estuary, the smectite values are slightly lower but still high $(40-50 \%)$. The lowest 


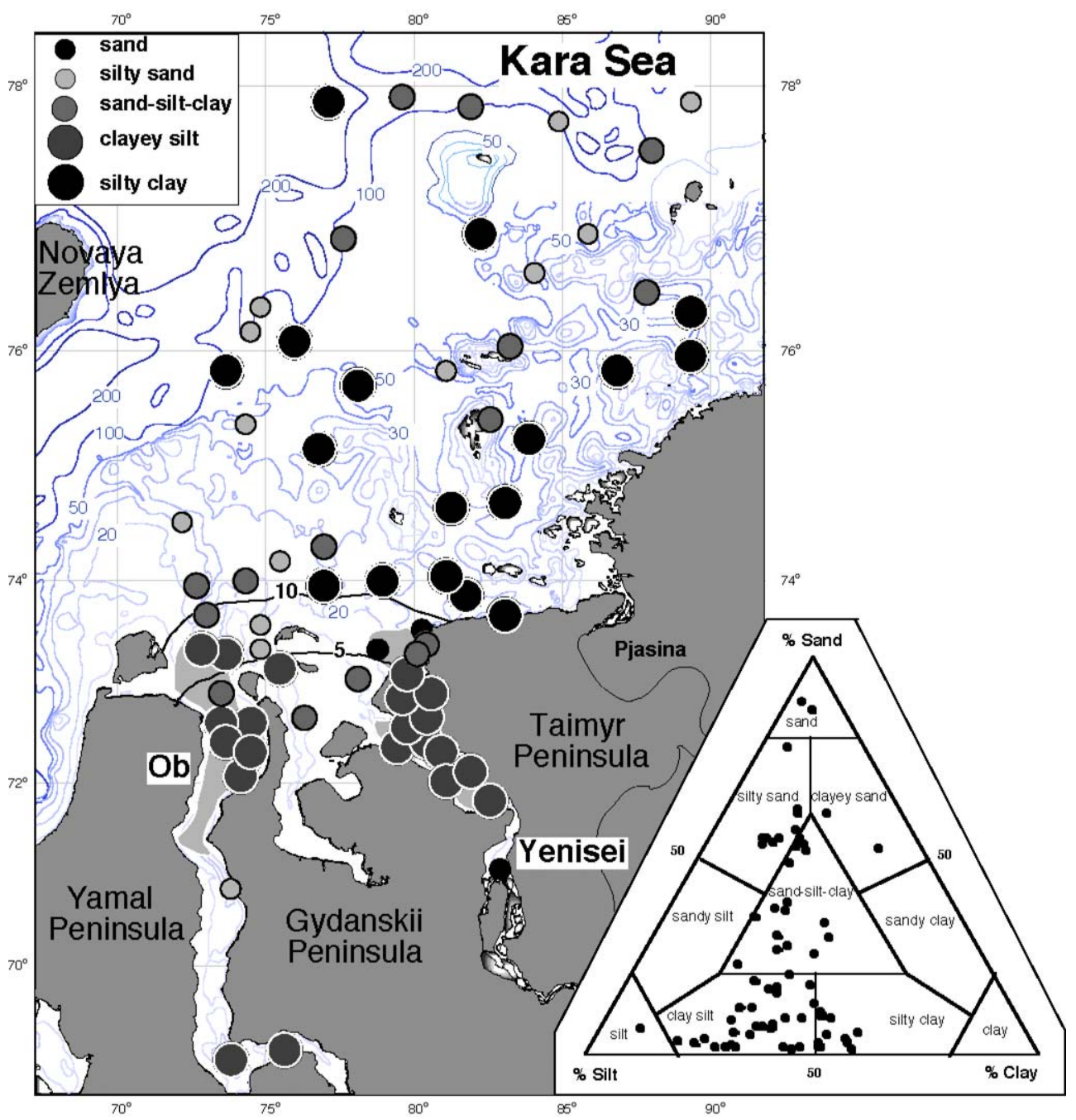

Fig. 4. Grain-size distribution in surface sediments of the southern Kara Sea (for data source see Steinke, 2002).

smectite contents of $<40 \%$ occur in the northern part of the study area. Illite contents vary between $18 \%$ and $43 \%$. Maximum illite values of $>35 \%$ occur in the northern area in water depths $>100 \mathrm{~m}$ (Fig. 5b). In Ob Estuary and the central part of the study area, illite contents reach 25-35\%. In the Yenisei Estuary and the adjacent southern Kara Sea, illite values are $<25 \%$ (Fig. 5b).

Kaolinite and chlorite are of secondary importance, only reaching $<25 \%$. Some higher kaolinite percentages of $>15 \%$ were determined on a transect from the Yenisei Estuary towards the north (Fig. 5c). Elevated chlorite values of $>15 \%$ occur in the estuaries and in the northern part of the study area (Fig. 5d).

A useful proxy to distinguish between the $\mathrm{Ob}$ and Yenisei sediment input seems to be the (smectite + kaolinite)/illite (SKI) ratio. The surface sediments of the Yenisei Estuary are characterized by a SKI ratio of $>2.5$ whereas the $\mathrm{Ob}$ sediments display a SKI ratio of $<2.5$ (Fig. 6). High SKI ratios determined in sediments west and northeast of the Yenisei Estuary (Fig. 6) are related to current-transported fine-grained material from the Yenisei (see Section 4).

\subsection{3. $M S$}

The porosity-corrected MS of surface sediments shows two major trends (Fig. 7). The first is that values for the Yenisei river are significantly higher than in the $\mathrm{Ob}$ area with averages at $3000-4000 \times 10^{-6} \mathrm{SI}$ and $<1000 \times 10^{-6} \mathrm{SI}$, respectively. The other important observation is a distinct decrease in values north of $74^{\circ} \mathrm{N}$ which is most pronounced in the Yenisei area. Despite the distinct decrease off the Yenisei Estuary some samples north of $74^{\circ} \mathrm{N}$ show slightly increased susceptibility compared to other areas of the southern Kara Sea.

\subsubsection{Amount and composition of organic carbon}

In Fig. 8, the TOC content of surface sediment samples are shown. The highest TOC values occur in the 

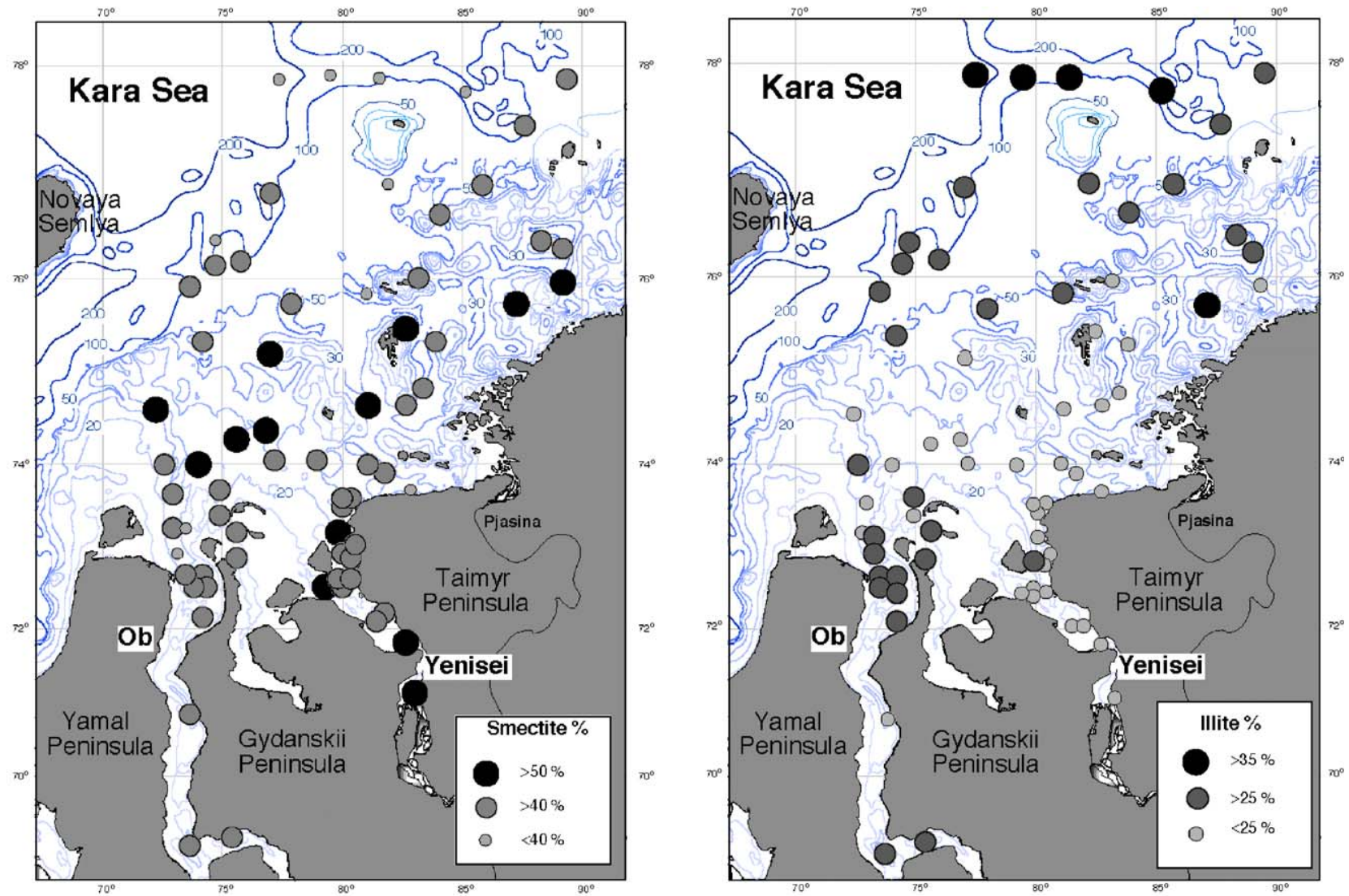

(A)

(B)
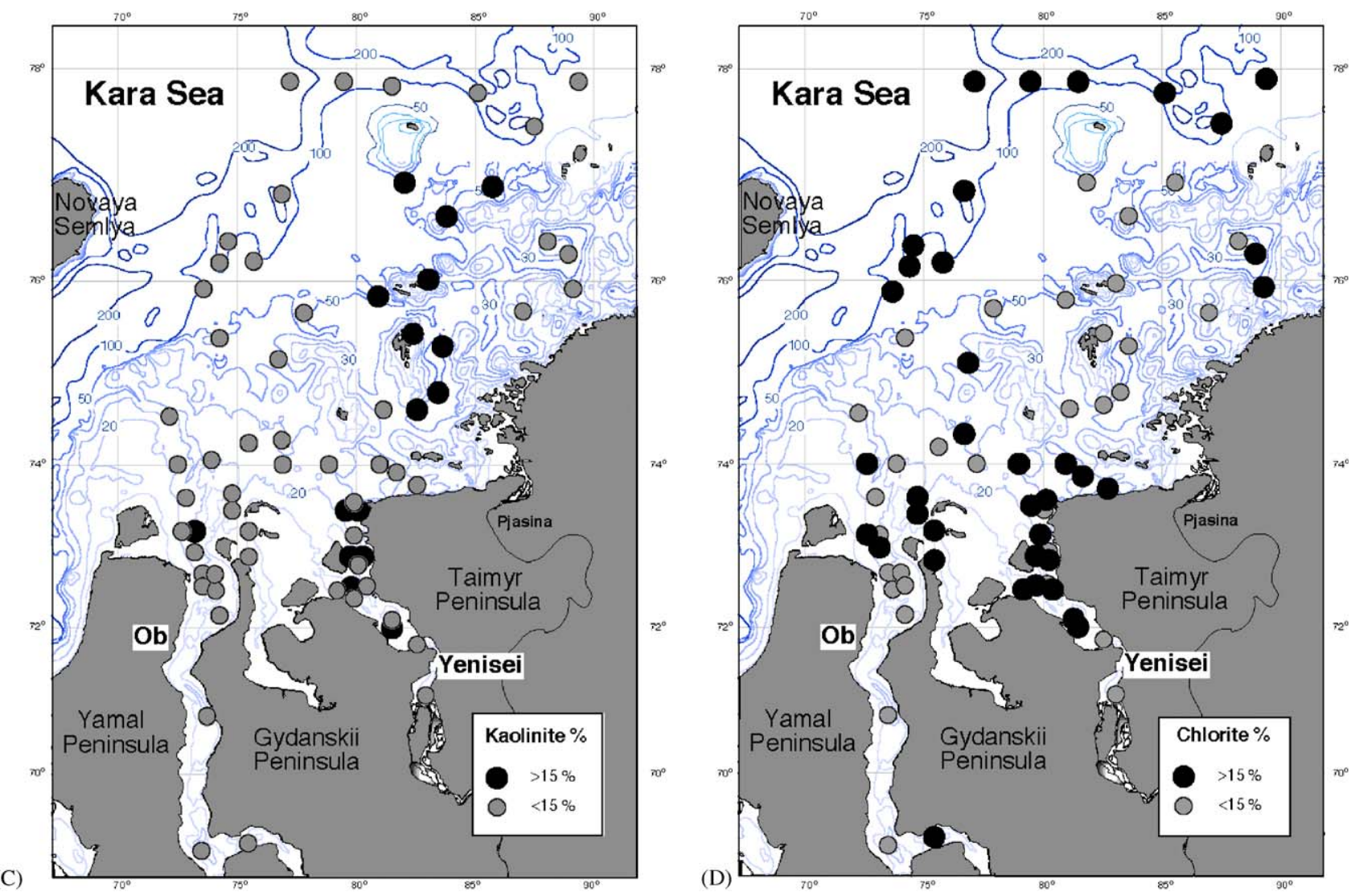

Fig. 5. Clay mineral composition of surface sediments of the southern Kara Sea (for data source see Steinke, 2002). (a) smectite, (b) illite, (c) kaolinite, and (d) chlorite (for data source see Steinke, 2002). 


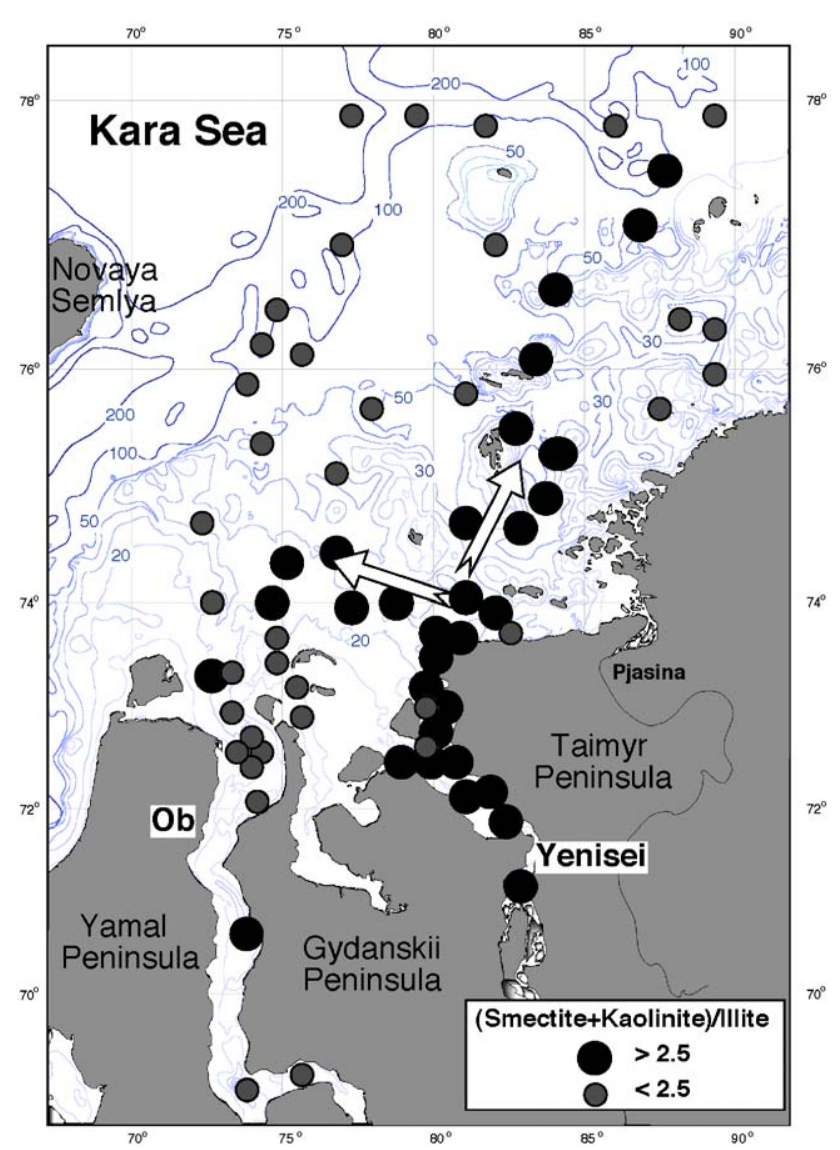

Fig. 6. SKI ratio of surface sediments of the southern Kara Sea (for data source see Steinke, 2002).

$\mathrm{Ob}$ and Yenisei estuaries where values of $>2 \%$ are reached. High TOC values were also determined in some samples from the submarine channels north of the Yenisei Estuary. The shallower areas outside the channels are characterized by lower TOC values. In the northern Kara Sea, elevated TOC values of $1-2 \%$ occur in the St. Anna Trough and the Voronin Trough, separated by characteristically low OC values in the Central Kara Plateau, and within a narrow rim around Franz Josef Land and in the deeper part (water depth $>300 \mathrm{~m}$ ) of the area between Franz Josef Land and Novaya Zemlya (Fig. 8).

The predominantly terrigenous origin of organic carbon in the southern Kara Sea and, especially in the estuaries, is clearly reflected in high $\mathrm{C} / \mathrm{N}$ ratios between 9 and 14 (Fig. 9), low hydrogen index values $<100 \mathrm{mg}$ $\mathrm{HC} / \mathrm{g}$ TOC as well as light $\delta^{13} \mathrm{C}_{\text {org }}$ values of about $-27 \%$ (Yenisei) and -28 to $-28.7 \%$ (Ob) (Krishnamurthy et al., 2001; Fahl et al., 2003; Stein and Fahl, 2003a). High concentrations of long-chain $n$-alkanes $\left(\mathrm{C}_{27}+\mathrm{C}_{29}+\mathrm{C}_{31}\right)$ indicative for higher terrestrial plant input, also support a terrigenous origin of the organic carbon (Fig. 9; Fernandes and Sicre, 2000; Fahl et al., 2003; Stein and Fahl, 2003a). A general decrease in relative proportion of terrigenous organic carbon towards the north is obvious (Fig. 9).

\subsubsection{Freshwater diatoms and palynomorphs}

The highest relative abundances of freshwater diatoms $(>90 \%)$ are characteristic for the $\mathrm{Ob}$ and Yenisei estuaries (Figs. 10 and 11). Seaward, a steep decrease in freshwater diatoms down to $<40 \%$ occurs at about $74^{\circ} \mathrm{N}$. A very similar picture is obvious in palynomorph data. In Fig. 11 we show the distribution of dinoflagellate cysts and the selected chlorophycean algae genus Pediastrum spp. along the $\mathrm{Ob}$ and Yenisei transects. Abundances of palynomorphs are expressed as concentrations per gram dry sediment. Both transects display a comparable distribution of palynomorphs. Pediastrum spp. is abundant in the inner estuaries and show a pronounced decline in the outer estuaries. Dinoflagellate cysts are inversely correlated to Pediastrum spp. The estuaries are marked by low concentrations increasing offshore north of $73^{\circ} \mathrm{N}$ (Fig. 11).

\subsection{Major lithologies of sediment cores and acoustic units}

In the studied sediment cores (Table 2) two lithological units can be distinguished. The predominant lithology of Unit I (Holocene) is a bioturbated clayey silt to silty clay (Fig. 12; Stein et al., 2003a) with quartz and clay minerals as major components (e.g. Stein and Stepanets, 2000). Unit II (post-glacial to Early Holocene) was only cored at stations BP01-26, BP99-38, BP99-05, BP99-36 and BP00-22 (Fig. 12). Unit II exhibits generally coarser sediments ranging from sandy clayey silt to clayey silty sand, and bioturbation is very rare (Stein and Stepanets, 2000; Stein et al., 2003a). Occasionally plant debris occurs as wood fragments, but aquatic fossil fragments like mollusc shells are absent. Often, distinct lamination is observed which is disrupted by some erosional contacts. In general, the upper part of Unit I displays the lowest MS values gradually increasing down-core. Similar to the density records, the transition from Unit I into Unit II is often characterized by a steep gradient with peak susceptibility at the boundary between Unit I and Unit II (Dittmers et al., 2003).

The two lithological units generally correlate with two major acoustic units (Unit I and Unit II) distinguished in the echograph profiles. Both units are separated by a distinct reflector (Fig. 2; Stein et al., 2000; Dittmers et al., 2003). The echosounding profiles obtained during "Akademik Boris Petrov" expeditions were used to determine and map the thickness of Unit $\mathrm{I}$ in the $\mathrm{Ob}$ and Yenisei estuaries and adjacent southern Kara Sea (Fig. 13). Between profile lines, unit thicknesses were interpolated. The highest sediment thicknesses occur in the estuaries between $72^{\circ}$ and $73^{\circ} 30^{\prime} \mathrm{N}$. Further north, 


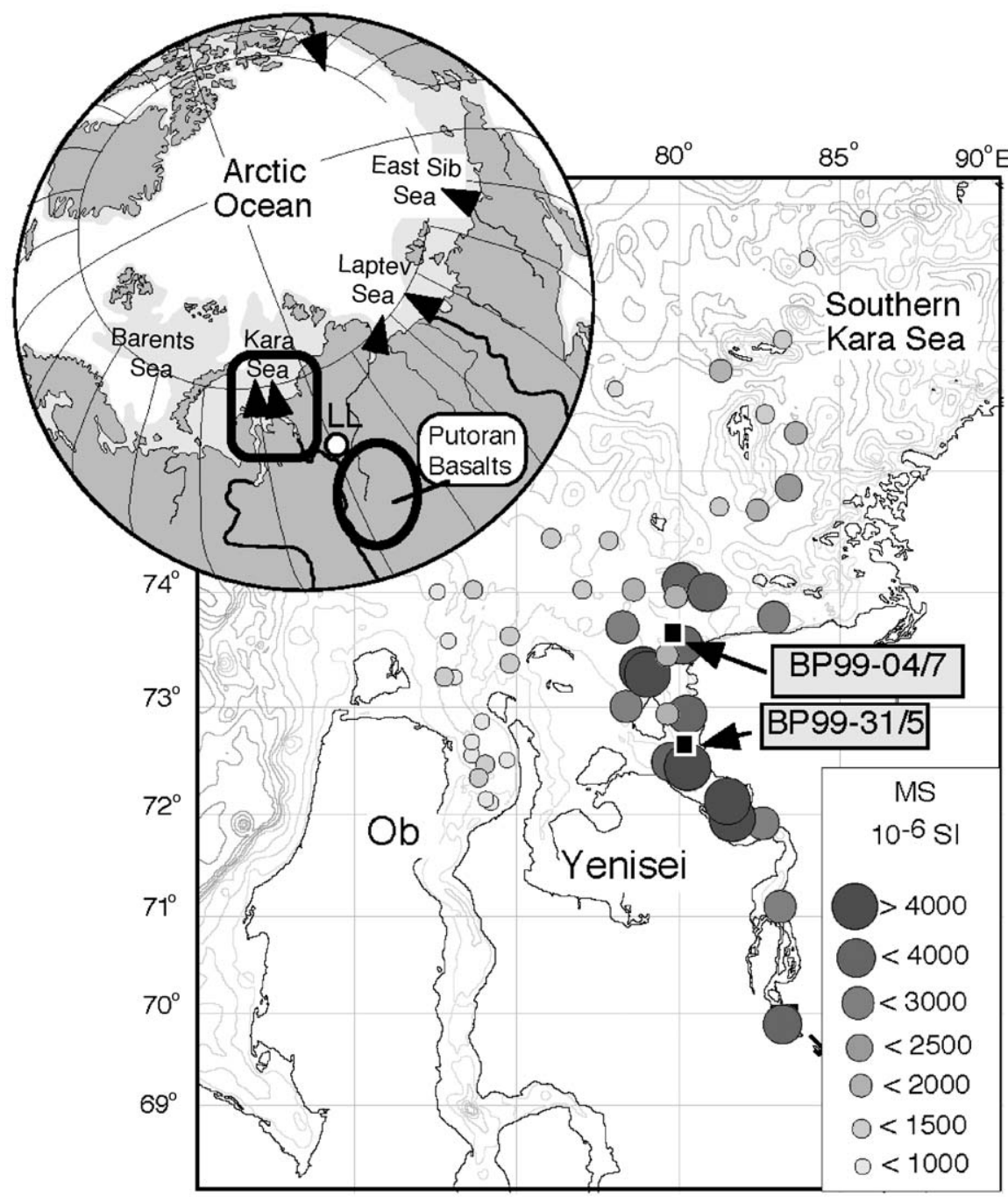

Fig. 7. Porosity-corrected MS values $\left(10^{-6} \mathrm{SI}\right)$ in surface sediments. Location of investigated sediment cores BP99-04/7 (see Fig. 19) and BP99-31/5 (see Fig. 18) are indicated by black squares. The overview map of northern Eurasia and adjacent the Arctic Ocean indicate the major Eurasian rivers draining into the Arctic Ocean (black triangles), the study area, the occurrence of Triassic flood basalts of the Putoran Massif (Duzhikov and Strunin, 1992), and the location of the Lama Lake (LL).

Unit $I$ is virtually absent on the shallow shelf and deposition is concentrated in morphological depressions and sediment sinks such as channels and paleovalleys (see Fig. 2).

In the narrower Yenisei Estuary, the sediment cover appears more canalised and extends further to the north than in the $\mathrm{Ob}$ Estuary (Fig. 13). Maximum sediment thickness of $20 \mathrm{~m}$ is found at $73^{\circ} \mathrm{N}$ in the Yenisei Estuary. From there northward, an approximately $15 \mathrm{~m}$ thick sediment blanket extends to $73^{\circ} 30^{\prime} \mathrm{N}$ (Fig. 13). North of this position, sediment thickness decreases distinctly, although in two elongated areas, thicknesses of up to $10 \mathrm{~m}$ continue further north up to $74^{\circ} \mathrm{N}$. In the $\mathrm{Ob}$ Estuary, areas with higher sediment thicknesses are wider but do not extend as far north as in the Yenisei Estuary (Fig. 13). Here, the maximum sediment thickness is reached at $72^{\circ} 20^{\prime} \mathrm{N}$. North of $72^{\circ} 50^{\prime} \mathrm{N}$ increased sediment thickness occurs along a south to north directing axis following $73^{\circ} \mathrm{E}$. There is a second area with lower sediment thickness of up to $10 \mathrm{~m}$ extending in a SW-NE direction near $74^{\circ} \mathrm{E}$

\section{Discussion}

\subsection{Surface sediment characteristics and modern terrigenous sediment supply in the southern Kara Sea}

The Kara Sea is characterized by its strong influence of river discharge (Table 1). Most of this discharge is related to the major rivers $\mathrm{Ob}$ and Yenisei. This huge water and suspended matter discharge is clearly reflected in the siliciclastic as well as biogenic fractions of surface sediments. Furthermore, the siliciclastic compounds allow to distinguish between $\mathrm{Ob}$ and Yenisei sediment input. 


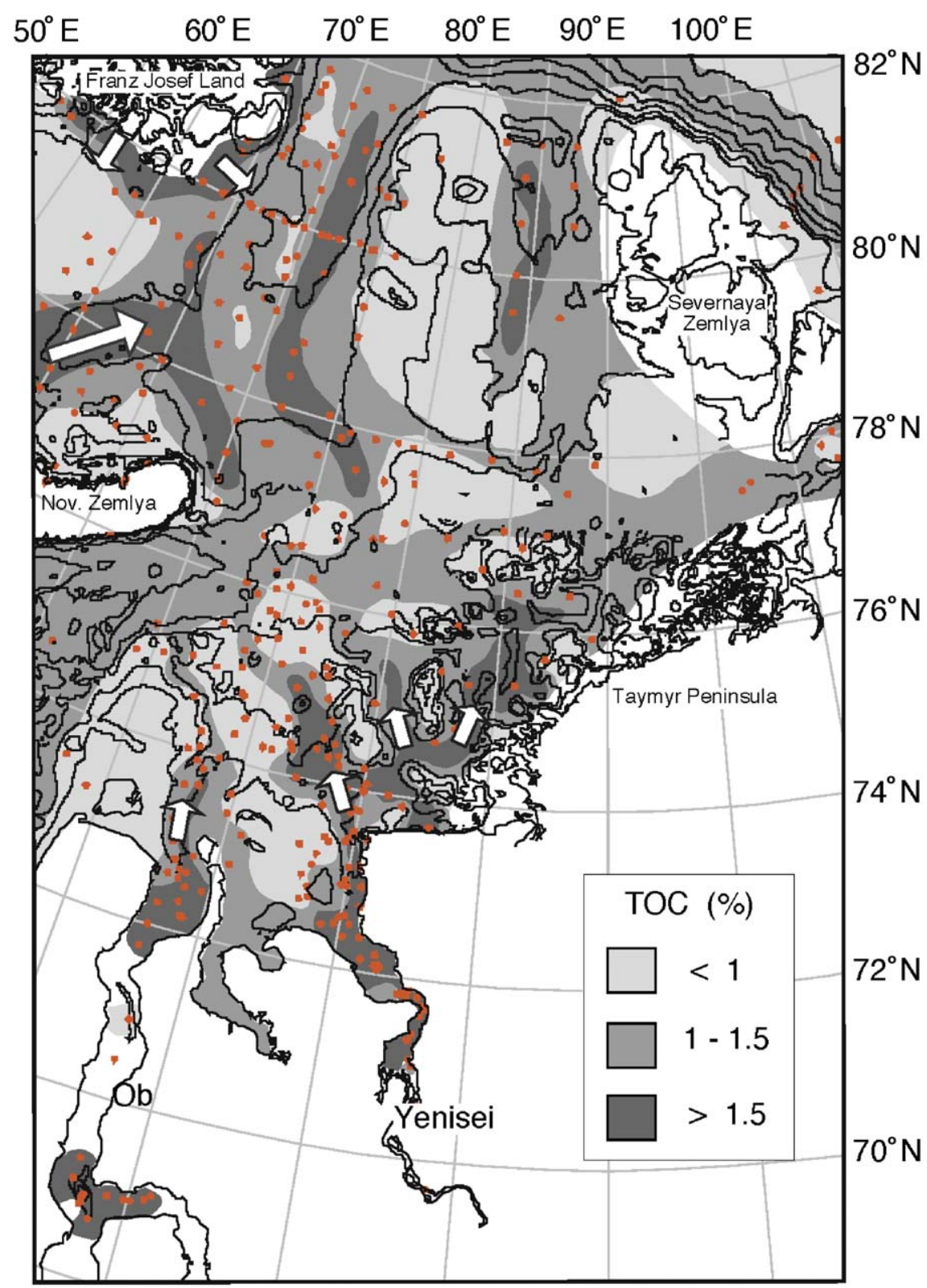

Fig. 8. Distribution map of TOC concentrations in the Kara Sea surface sediments (for data source see Stein and Fahl, 2003a). Open arrows indicate input and pathways of organic carbon.

A major source of the suspended matter of the Yenisei River are the widespread Triassic plateau basalts and tuff deposits of the Putoran Massif (Fig. 7; Duzhikov and Strunin, 1992). About $70 \%$ of the modern annual Yenisei discharge is contributed by the main tributaries Nizhnyaya Tunguska River and Podkamennaya Tunguska River, draining this area (Meade et al., 2000). Basalts and their weathering products are generally characterized by high MS (MS) values (Thompson and Oldfield, 1986). The relationship between riverine input from basaltic source areas and MS values is clearly reflected in surface sediments from the Kara Sea (Fig. 7). The Yenisei-influenced sediments have very high MS values whereas the sediments supplied by the river $\mathrm{Ob}$ draining the Siberian lowlands, are characterized by very low MS values (Fig. 7).

Yenisei suspended matter input can also be identified by the clay mineral composition. Here, the "SKI" ratio seems to be a very useful proxy (Fig. 6). Sediments from the Yenisei Estuary are characterized by high SKI ratios. High ratios also occur in the depressions towards the NNE and correlate with maximum clay content in surface sediments (Figs. 4 and 6). This distribution pattern probably reflect the main transport of finegrained Yenisei material by surface-water currents during autumn and winter (see Harms et al., 2000). 


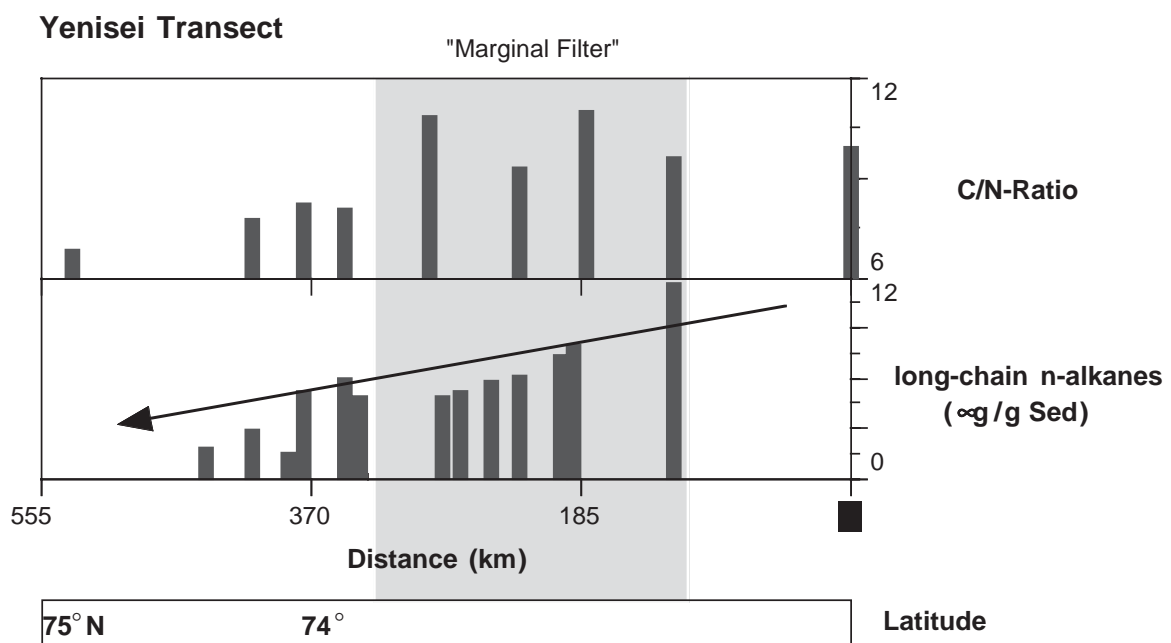

Ob Transect $\quad$ "Marginal Filter"

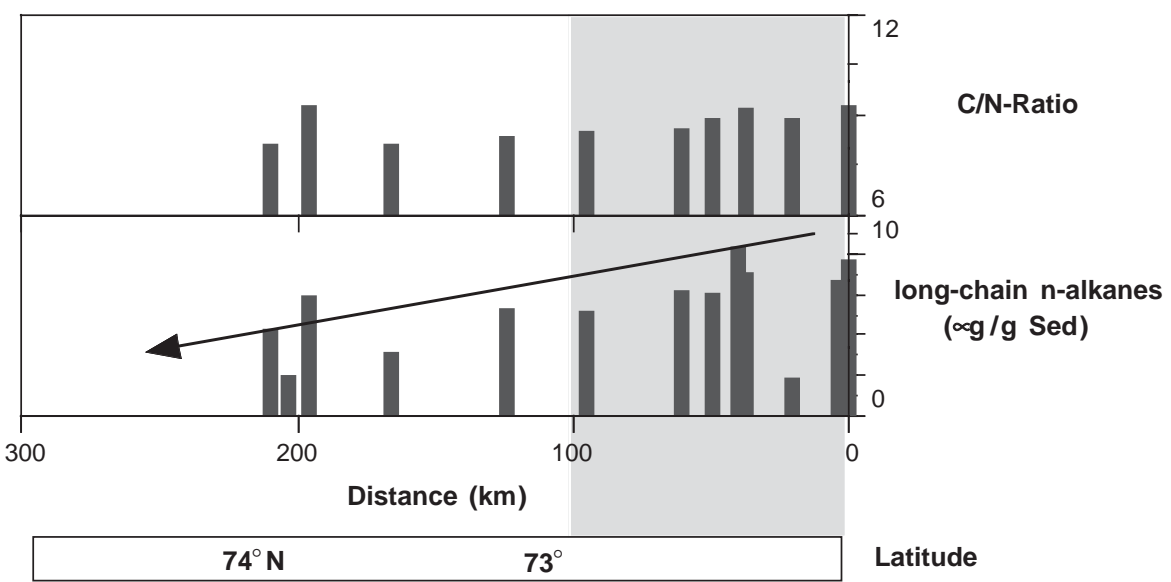

Fig 9. $\mathrm{C} / \mathrm{N}$ ratios and relative concentrations of long-chain $n$-alkanes in surface sediments of the Yenisei and Ob transects. For data source we refer to Fahl et al. (2003). The positions of the marginal filter is indicated as gray bar.

During spring/summer, the main surface-water circulation pattern is characterized by currents towards the west which may explain the second SKI maximum in a westward direction (Fig. 6).

Concerning biogenic components, freshwater diatoms and freshwater/terrestrial palynomorphs are transported to the shelf zone by rivers (e.g., Cremer, 1999; Naidina and Bauch, 1999; Matthiessen et al., 2000; Polyakova, 2003). Their distribution in the surface sediments of the $\mathrm{Ob}$ and Yenisei estuaries and adjacent Kara Sea clearly reflects river runoff. The highest relative abundances of freshwater diatoms $(>90 \%)$ as well as high absolute abundances of the chlorococcalean algae genus Pediastrum spp. are characteristic for the $\mathrm{Ob}$ and Yenisei estuaries with salinities less than 10 (Fig. 11). Seaward, the overall decrease of abundances of freshwater diatoms and the chlorococcalean algae genus Pediastrum spp. is related to the decreasing influence of the riverine water. The steep decrease in freshwater species occur at about $73^{\circ} \mathrm{N}$ in the $\mathrm{Ob}$ Estuary and at about $73^{\circ} 30^{\prime} \mathrm{N}$ in the Yenisei Estuary (Fig. 11). This border approximately corresponds to the outer boundary of the "marginal filter" in the Kara Sea (Fig. 1; Lisitzin, 1995).

The distribution pattern of TOC content in the surface sediments, related to the riverine suspended matter input, display a very similar picture (Fig. 8). In the estuaries functioning as marginal filter, most of the fine-grained suspension including the organic matter is already trapped and accumulating. This is reflected in absolute TOC maxima $>2 \%$ measured in the central estuaries, the positive correlation between TOC content and amount of fine fraction $<63 \mu \mathrm{m}$ (compare Figs. 4 and 8, for correlation diagram see Stein and Fahl, 2003a), and maximum thicknesses of Holocene sediments (Fig. 13). The high TOC values of $>1.5 \%$ within the narrow rim around Franz Josef Land and in the deeper part of the area between Franz Josef Land and Novaya Zemlya are probably related to input of 


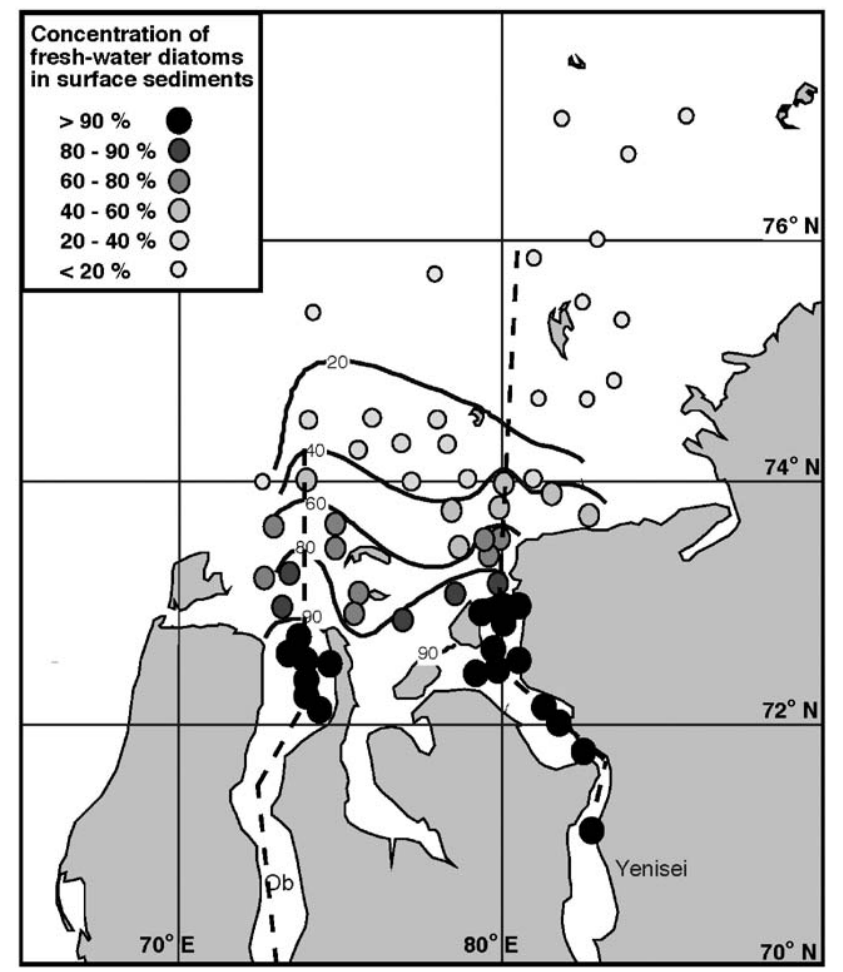

Fig. 10. Distribution map of freshwater diatoms in surface sediments. Stippled lines indicate position of transects shown in Fig. 11. For data source see Polyakova (2003).

terrigenous matter from Franz Josef Land and to organic carbon input from the Barents Sea via Atlantic water inflow, respectively (Fig. 8).

\subsection{Holocene changes in sediment accumulation and paleoenvironmental significance}

The late Quaternary paleoenvironmental evolution of the Kara Sea and the related sediment input have been strongly influenced by changes in river discharge, coastal erosion, sea-ice cover, and oceanic circulation patterns as well as the waxing and waning of the Barents-Kara Ice Sheet (e.g., Polyak et al., 1997, 2002a, b; Velichko et al., 1997; Svendsen et al., 1999; Lubinski et al., 2001; Mangerud et al., 2002; Stein et al., 2003a). During the last glacial maximum (LGM), major parts of the northern Kara Sea were covered by an ice sheet, whereas in the southern Kara Sea the ice front was located along the southern and eastern margin of the Novaya Zemlya Trough, i.e., the southern Kara Sea was probably ice-free (e.g., Svendsen et al., 1999; Polyak et al., 2002a, b; Stein et al., 2002; see Svendsen et al., this volume, for a synthesis). That means, at that time the shallow southern Kara Sea was subaerially exposed due to the lowered glacial sea level (Fig. 14; Fairbanks, 1989), and terrigenous (fluvial) sediments were transported much farther to the north. With the postglacial sea-level rise, the shallow Kara Sea became widely flooded (Fig. 14). Unfortunately, LGM sediments were not recovered in our studied sediment cores.

Studies of the late Quaternary paleoenvironmental history based on sediment cores from the Kara Sea are still very rare. Levitan et al. (1995) performed sedimentological and micropaleontological investigations of sediment cores obtained from the "Dmitry Mendeleev" in 1993 (Lisitzin and Vinogradov, 1995). Due to the absence of any absolute $\mathrm{AMS}^{14} \mathrm{C}$ age control, precise climatic reconstructions and correlations with similar data sets from the Barents and Laptev seas have not been possible. Based on a study of $\mathrm{AMS}^{14} \mathrm{C}$ dated sediment cores from the St. Anna Trough, more detailed information about the glacial/deglacial history and related Atlantic water and freshwater inflows in the northern Kara Sea became available (Polyak et al., 1997; Lubinski et al., 2001; Boucsein et al., 2002). The recovery of glacigenic diamictons in sediment cores from the St. Anna Trough provides evidence for grounded glacier ice which may have reached the shelf edge during the Last Glacial Maximum (Polyak et al., 1997). Based on $\mathrm{AMS}^{14} \mathrm{C}$ dated sediment cores from the southern Kara Sea obtained within the SIRRO Project (Fig. 12; Table 2), a detailed picture can be constructed of the changes in terrigenous siliciclastic and organic carbon fluxes in the southern Kara Sea during (deglacial to) Holocene times and their relationship to climate change and sea-level rise.

Accumulation rates of total sediment give information about the spatial and temporal variability of total sediment flux. The changes in accumulation rates in the inner and central Kara Sea are strongly related to the post-glacial sea-level rise (Fig. 14). In the earliest Holocene (10-11 Cal. kyr BP), maximum accumulation rates were recorded in the central Kara Sea (Fig. 15). Accumulation rates of total sediment reach very high values of about $150-700 \mathrm{~g} \mathrm{~cm}^{-2} \mathrm{kyr}^{-1}$. At that time, the sea level was about $40-50 \mathrm{~m}$ lower than today and large parts of the inner Kara Sea were subaerial (Fig. 14). Terrigenous sediments were transported much more to the north, and the main depocenter was situated more toward the central Kara Sea (Fig. 16).

Maximum accumulation rates were almost contemporaneously determined in the eastern Kara Sea at Core PS2719/1 (Figs. 14 and 15; Stein et al., 2001) as well as in a large number of sediment cores from the St. Anna Trough in the northern Kara Sea (Herlihy, 1996; Polyak et al., 1997) and the Laptev Sea (e.g.,; Stein and Fahl, 2000, 2003b; Bauch et al., 2001a, b). The correspondence between these cores means that between 9 and 11 Cal. kyr BP the supply of terrigenous matter sharply increased along the entire Kara Sea-Laptev Sea continental margin. This maximum in terrigenous sediment accumulation occurred at a time of a major postglacial sea-level rise (Fairbanks, 1989), when the shallow inner Kara Sea and Laptev Sea shelf became 

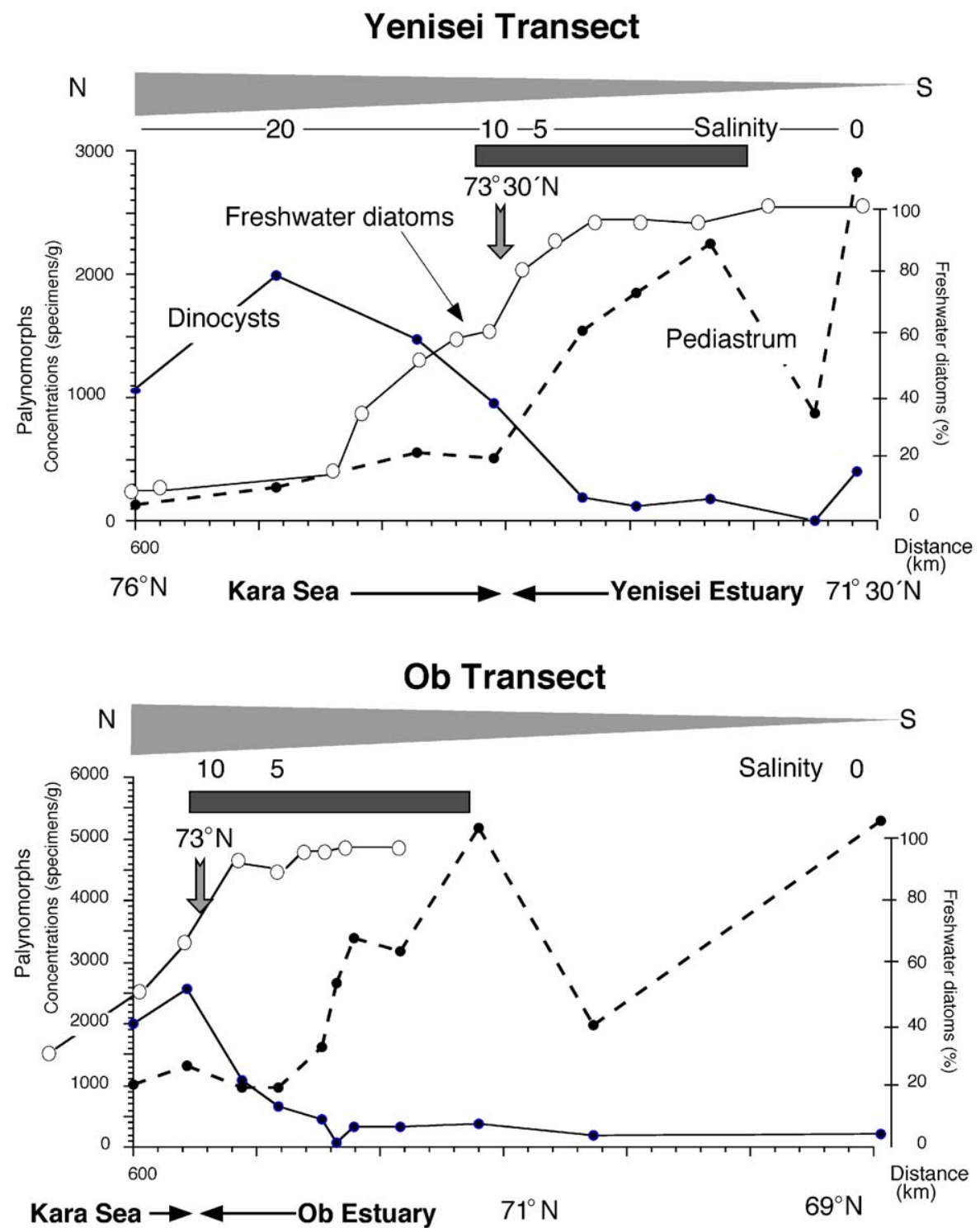

Fig. 11. Distribution of freshwater diatoms, dinoflagellate cysts and Pediastrum spp. along the Ob and Yenisei transects. Salinity data are from Burenkov and Vasil'kov (1995). Dark gray bars indicate location of marginal filter. For location of transects see Fig. 10.

Table 2

Core location and water depth of investigated sediment cores

\begin{tabular}{lllc}
\hline Station & Latitude $\left({ }^{\circ} \mathrm{N}\right)$ & Longitude $\left({ }^{\circ} \mathrm{E}\right)$ & Water depth $(\mathrm{m})$ \\
\hline BP99-04/7 & $73^{\circ} 24.89^{\prime}$ & $79^{\circ} 40.48^{\prime}$ & 32 \\
BP99-05/1 & $73^{\circ} 30.097^{\prime}$ & $80^{\circ} 0.662^{\prime}$ & 38 \\
BP00-07/7 & $74^{\circ} 39.456^{\prime}$ & $81^{\circ} 08.466^{\prime}$ & 38 \\
BP00-14/3 & $72^{\circ} 55.853^{\prime}$ & $79^{\circ} 47.381^{\prime}$ & 19 \\
BP00-22/4 & $72^{\circ} 33.990^{\prime}$ & $79^{\circ} 54.927^{\prime}$ & 11 \\
BP00-23/6 & $73^{\circ} 28.542^{\prime}$ & $79^{\circ} 51.348^{\prime}$ & 33 \\
BP00-26/4 & $75^{\circ} 42.512^{\prime}$ & $77^{\circ} 57.589^{\prime}$ & 68 \\
BP00-29/4 & $76^{\circ} 56.17^{\prime}$ & $85^{\circ} 45.79^{\prime}$ & 68 \\
BP00-36/4 & $76^{\circ} 57.707^{\prime}$ & $81^{\circ} 57.79^{\prime}$ & 66 \\
BP00-38/2 & $73^{\circ} 11.81^{\prime}$ & $73^{\circ} 14.31^{\prime}$ & 20 \\
BP01-39/2 & $77^{\circ} 06.7^{\prime}$ & $86^{\circ} 44.9^{\prime}$ & 106 \\
BP01-42/2 & $75^{\circ} 26.2^{\prime}$ & $86^{\circ} 03.7^{\prime}$ & 49 \\
BP01-61/7 & $76^{\circ} 12.9^{\prime}$ & $75^{\circ} 53.2^{\prime}$ & 111 \\
PS2719/1 & $77^{\circ} 36^{\prime}$ & $97^{\circ} 32^{\prime}$ & 135 \\
\hline
\end{tabular}

widely flooded for the first time after the LGM, resulting in large-scale sea floor/coastal erosion and, thus, a distinctly increased supply of terrigenous matter (e.g., Polyak et al., 1997; Stein and Fahl, 2000; Bauch et al., 2001a, b). The river discharge probably increased at the same time, transporting large amounts of riverine material towards the core locations.

With increasing sea level, sedimentation in the central Kara Sea became drastically reduced near 9 Cal. kyr BP (Fig. 15), and the main depocenter shifted towards the south, reaching approximately "modern" condition during the last 6 Cal. kyr BP (Fig. 16). Near 2 Cal.kyr BP, accumulation rates at site BP99-04/7 increased to values of up to about $75 \mathrm{~g} \mathrm{~cm}^{-2} \mathrm{kyr}^{-1}$. Similar contemporaneous trends, i.e., the increase in total sediment accumulation rates, are also observed in the Yenisei 


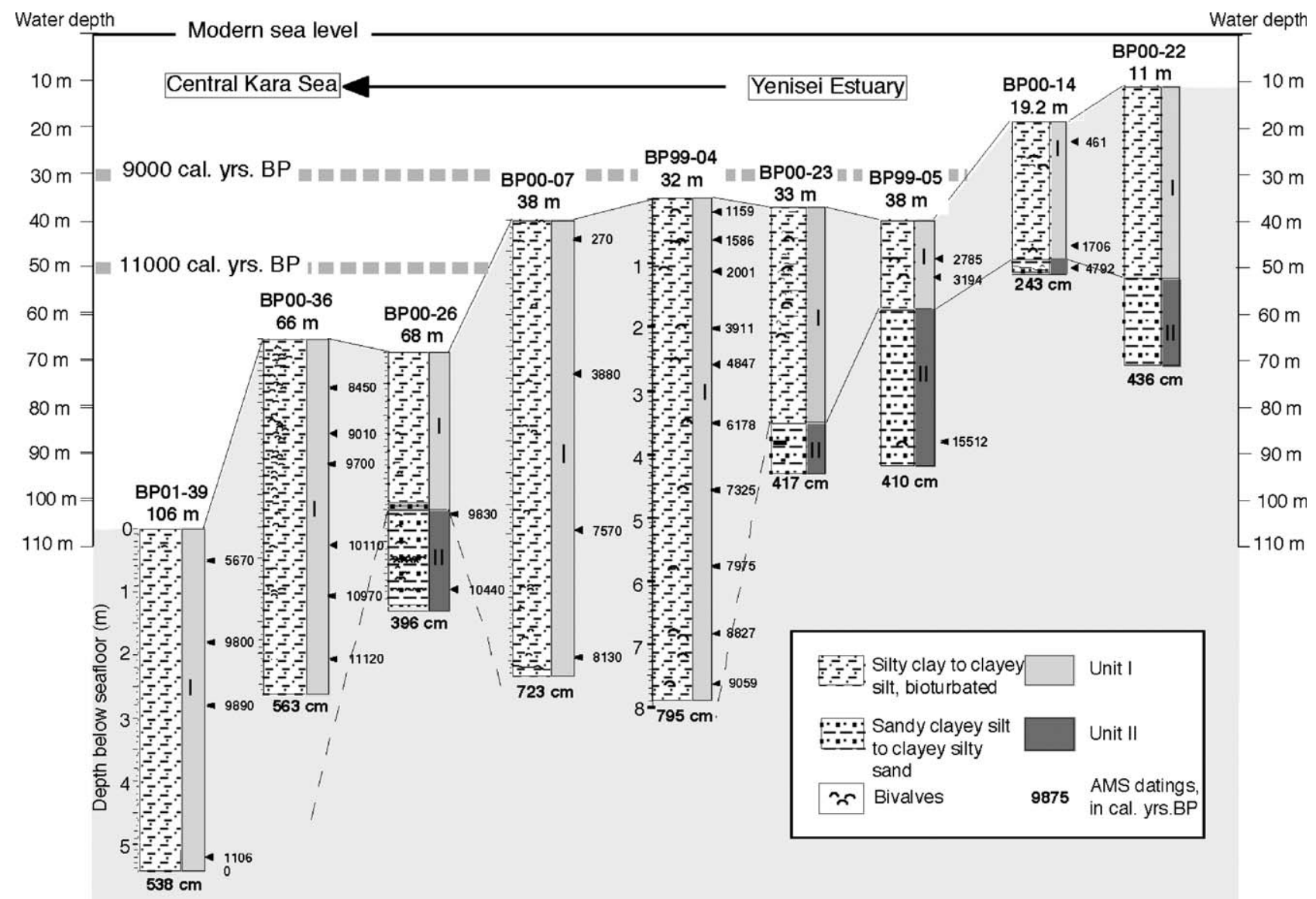

Fig. 12. Major lithologies of investigated sediment cores. Lithological units and $\mathrm{AMS}^{14} \mathrm{C}$ dates are shown. Cores are arranged according to increasing water depth from right (south) to left (north). Note the different scales for water depth and sediment cores. The approximate sea level at 9000 and 11000 Cal. yr BP (according to Fairbanks, 1989) are marked. See Fig. 3 for core locations.

Core BP00-14/3 and the Ob Core BP00-38/2 (Fig. 15). At the same time, accumulation rates decreased in the southern Kara Sea Core BP01-42/2 (Fig. 15), suggesting an increase in effectiveness of the marginal filter as sediment trap.

\subsection{Holocene total sediment budget of the Kara Sea}

The calculation of the average Holocene (11-0 Cal. kyr BP) budget (Table 3) is mainly based on the distribution map of average sedimentation rates shown in Fig. 17. This map was produced from Holocene sediment thickness charts (Bjelvin and Holm, 1993; Gurevich, 1995), sediment echograph profiling results (Stein et al., 2000; Stein, 2001; Niessen and Dittmers, 2002), penetration values of the gravity corer into soft (Holocene) sediments (Matthiessen et al., 1999; Stein and Stepanets, 2000, 2001, 2002), $\mathrm{AMS}^{14} \mathrm{C}$-dated sediment cores (Stein et al., 2003a), and the correlation of additional sediment cores to the $\mathrm{AMS}^{14} \mathrm{C}$-dated sediment cores using MS records (Dittmers et al., 2003). For the $\mathrm{Ob}$ and Yenisei area, the detailed mapping of Holocene sediment thickness (Fig. 13) has been con- sidered (Dittmers et al., 2003). For calculation of accumulation rates, average dry density data obtained from sediment cores were used (Stein et al., 2001; Dittmers et al., 2003; Stein and Fahl, 2003a). Whereas the budget calculations of the southern and central Kara Sea are supported by data from numerous $\mathrm{AMS}^{14} \mathrm{C}$ dated sediment cores, the data base for the northern Kara Sea is much weaker due to the limited number of available sediment cores (see Stein and Fahl, 2003a for detailed discussion of budgets of different Holocene time intervals as well as an organic carbon budget). In our own study, we have excluded the southwestern Kara Sea (see Fig. 1). For this part of the Kara Sea, we have taken data from Vetrov and Romankevich (2003).

Based on our data, average annual total sediment accumulation is about $22 \times 10^{6} \mathrm{tyr}^{-1}$ in the $\mathrm{Ob}$ and Yenisei estuaries (Table 3). In Gydanskii Bay, as part of the marginal filter, probably another $6 \times 10^{6} \mathrm{tyr}^{-1}$ of total sediment is accumulating. That means, approximately $28 \times 10^{6} \mathrm{tyr}^{-1}$ of total sediment are trapped in the marginal filter. In the southeastern, central, and northern Kara Sea, about $18 \times 10^{6}, 36 \times 10^{6}$ and $28 \times 10^{6} \mathrm{tyr}^{-1}$, respectively, of total sediment is 
(A)
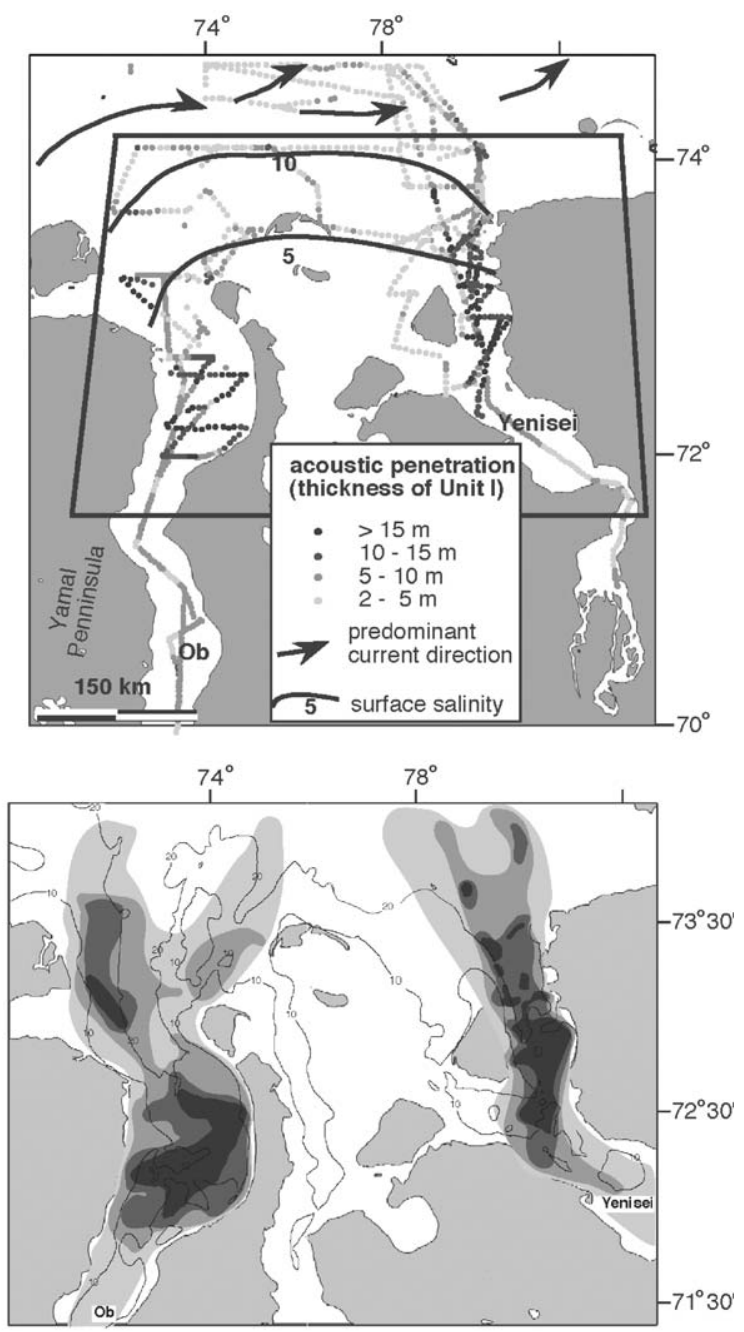

ELAC Sound Penetration

(B)

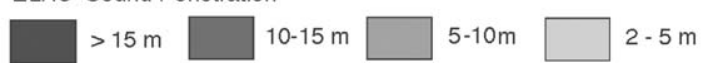

Fig. 13. (a) Data base of thickness quantification of Unit I (Holocene) by determination of acoustic penetration along ELAC/CHIRP profiles. Current direction and surface salinity after Pavlov and Pfirmann (1995). The trapeze indicates position of Fig. 7b. (b) Isopach map showing the total thickness and extend of acoustic Unit $\mathrm{I}$ in $\mathrm{Ob}$ and Yenisei estuaries based on ELAC/CHIRP profiles. Water depth in meters. For data source see Dittmers et al. (2003).

accumulating (Table 3). For the southwestern Kara Sea, about $83 \times 10^{6} \mathrm{tyr}^{-1}$ of total sediment is buried (based on an organic carbon accumulation of $0.83 \times 10^{6} \mathrm{t} \mathrm{yr}^{-1}$ and an average organic carbon content of $1 \%$; Vetrov and Romankevich, 2003). For the entire Kara Sea, all data can be summed up to an average Holocene accumulation of $194 \times 10^{6} \mathrm{tyr}^{-1}$ of total sediment. This is about $20 \%$ of the avarage Holocene sediment accumulation calculated for the entire Arctic Ocean $\left(1008 \times 10^{6} \mathrm{tyr}^{-1}\right.$ of total sediment; Stein and Macdonald, 2003).

According to the sedimentary records shown in Fig. 15 , the sediment accumulation in the Kara Sea changed
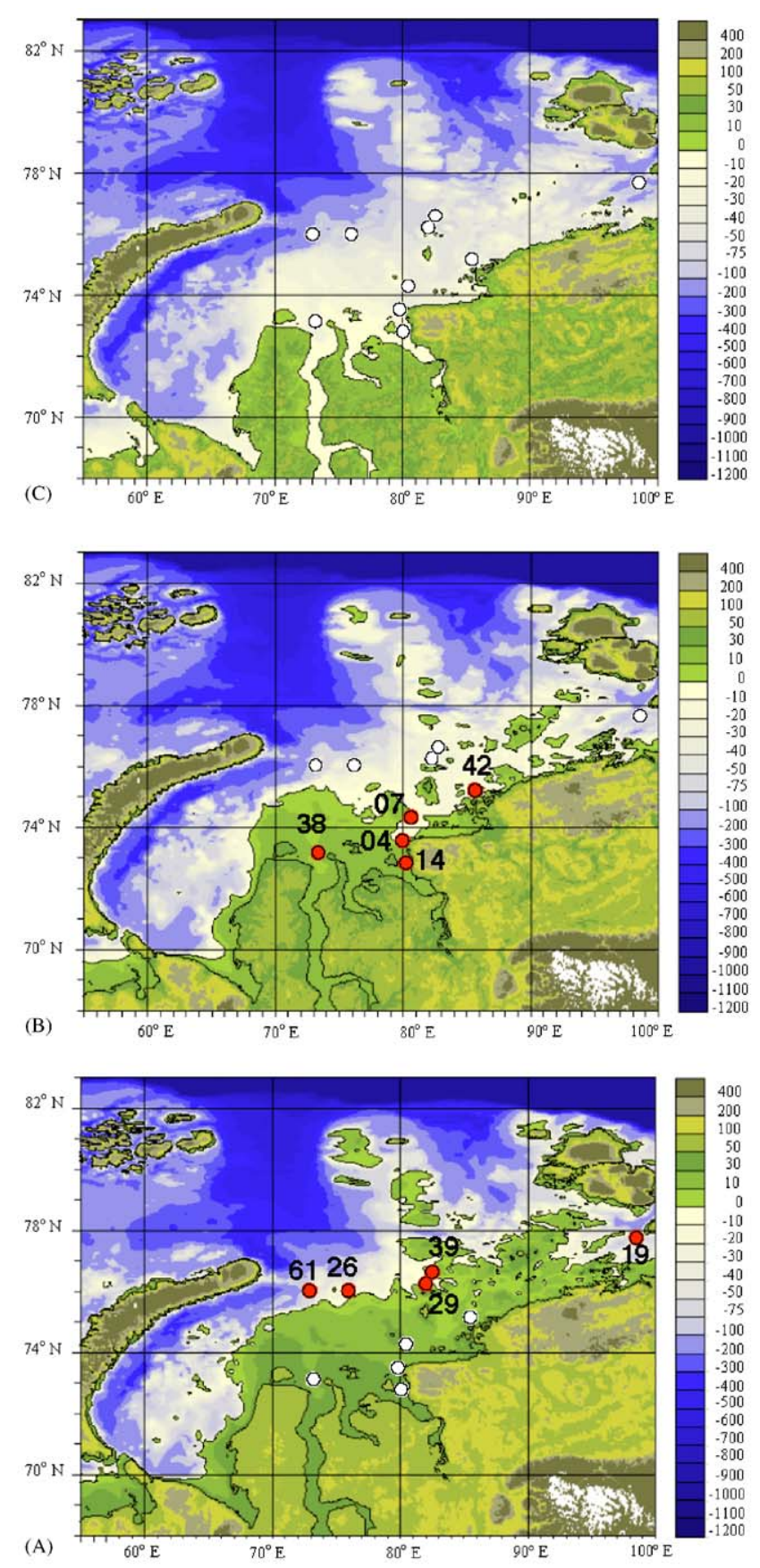

Fig. 14. Land/sea distribution in the Kara Sea at times of lowered global sea level (according to Fairbanks, 1989). The maps have been constructed simply by using the 30,50 and $100 \mathrm{~m}$ isolines of the modern bathymetry (assuming no or negligible isostatic rebound). Locations of cores BP99-04, BP00-07, BP00-14, BP00-26, BP00-29, BP00-38, BP01-39, BP01-42, BP01-61, and PS2719 are shown. Maps were drawn based on the IBCAO data set (I. Harms, Institute of Oceanography, Hamburg University): (a) about 11 Cal.kyr BP $(-50 \mathrm{~m})$, (b) 9 Cal. kyr BP $(-30 \mathrm{~m})$, and (c) modern situation.

drastically during the post-glacial Holocene sea level rise. During the early Holocene sediment accumulation was elevated, especially in the central Kara Sea, resulting in total sediment accumulation significantly 

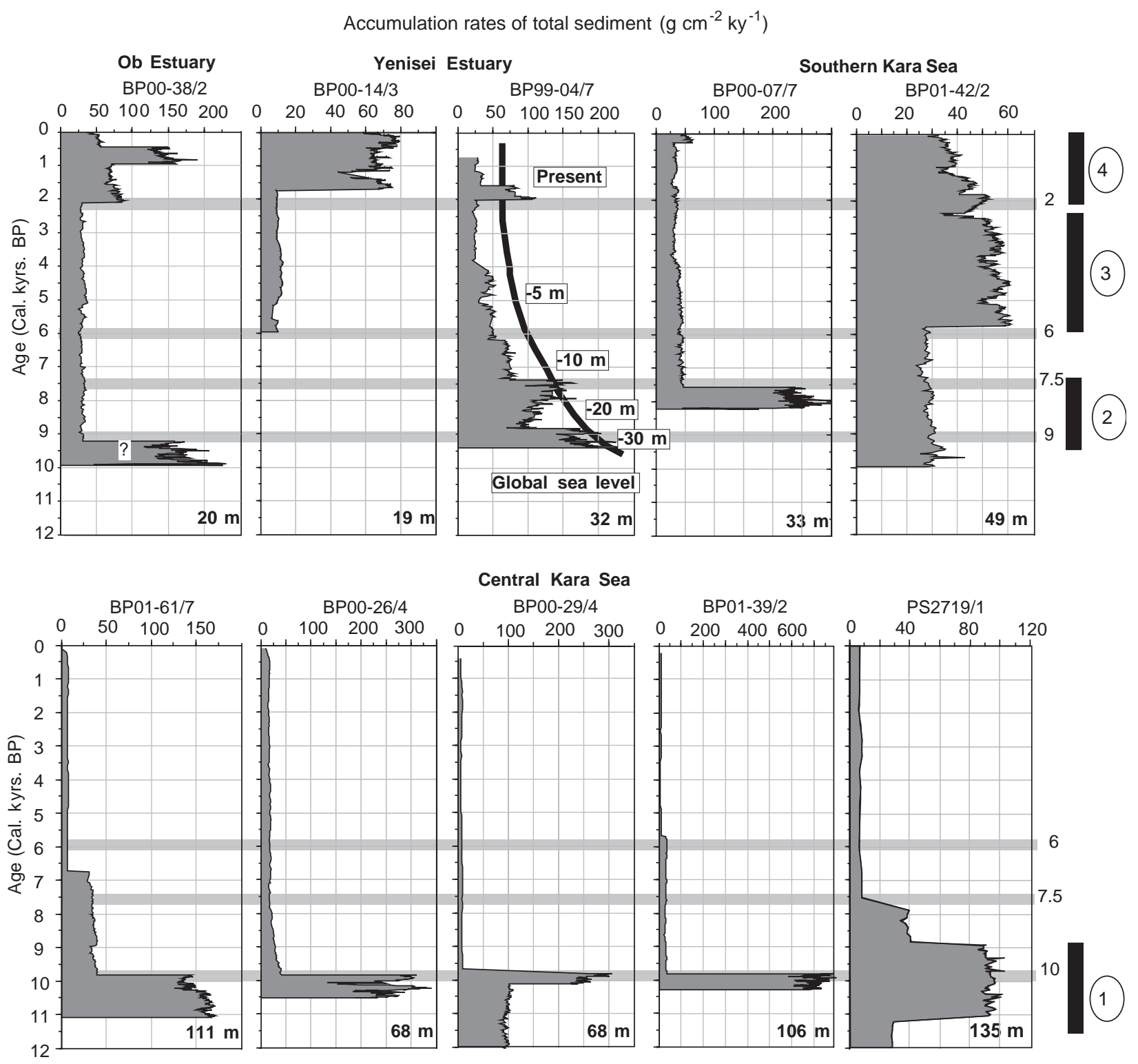

Fig. 15. Accumulation rate records of total sediments from the AMS- ${ }^{14} \mathrm{C}$ dated sediment cores. Horizontal gray bars with numbers at the right end highlight times of major changes in accumulation rates (ages in Cal. kyr BP) in steps 1-4 as discussed in the text. In the record of Core BP99-04/7, the global sea-level curve according to Fairbanks (1989) is shown.

higher than the average Holocene values given in Table 3. This is explained by an increased sediment input by coastal erosion and rivers at that time (see discussion above). On the other hand, during Late Holocene times the values are lower than the Holocene average. Based on sediment core data, Stein and Fahl (2003a) estimated a total sediment accumulation for the entire late Holocene (modern) Kara Sea of about $123 \times 10^{6} \mathrm{t} \mathrm{yr}^{-1}$, and they have related this value to the modern total sediment input of $150 \times 10^{6} \mathrm{tyr}^{-1}$ (Table 1). This gives in a Kara Sea export of about $27 \times 10^{6} \mathrm{t} \mathrm{yr}^{-1}$ (i.e., $18 \%$ of the total input) of total sediments. Since sea-ice export is probably very low $\left(2.4 \times 10^{6} \mathrm{tyr}^{-1}\right.$; Eicken in Rachold et al., 2003), most of this export (about
$25 \times 10^{6} \mathrm{tyr}^{-1}$ ) is related to ocean current transport, a number which is not unrealistic when looking at the Kara Sea net outflow values (Table 1). In their budget calculation, however, Stein and Fahl (2003a) have not considered sediment input from the Barents Sea via ocean currents (see below).

Concerning the question how much of the riverine suspended matter (i.e., about $41 \times 10^{6} \mathrm{tyr}^{-1}$; Table 1) may escape the marginal filter and is transported onto the open Kara Sea shelf, an estimate of $12 \times 10^{6} \mathrm{tyr}^{-1}$ (i.e., about $30 \%$ of the input) is given by Stein and Fahl (2003a), a value which is based on late Holocene sediment accumulation in the estuaries (see also Dittmers et al., 2003). That means, on a geological time 


\section{Main depocenter and pathway of terrigenous sediments}

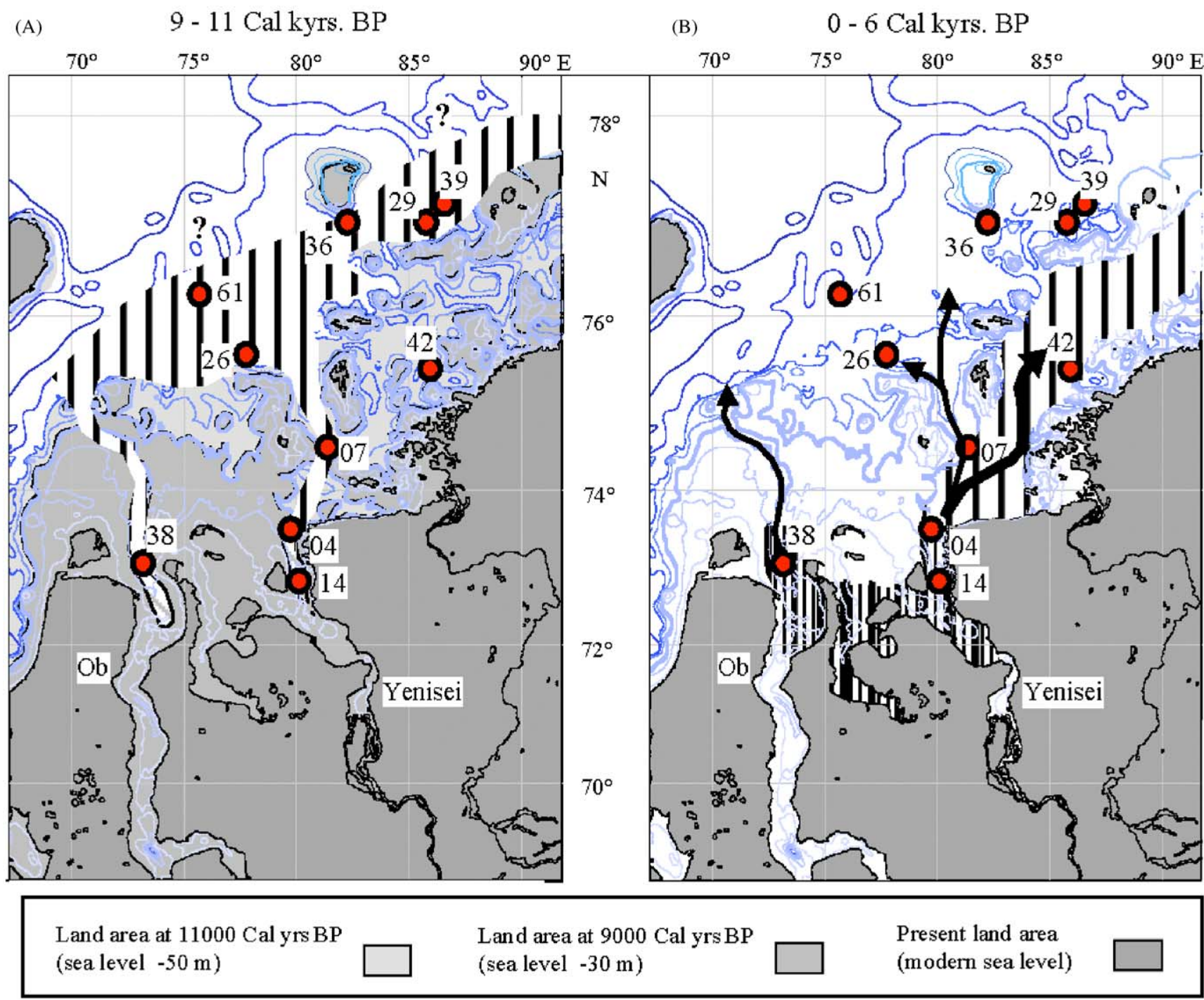

Fig. 16. Main depocenter and pathways of terrigenous matter during (A) the early Holocene (9-11 Cal. kyr BP) and (B) the late Holocene (06 Cal. kyr BP). The southern Kara Sea with land-ocean distribution at 9000 and $11,000 \mathrm{Cal}$. yr BP when the sea level was approximately 30 and $50 \mathrm{~m}$, respectively, lower than today (Fairbanks, 1989), is shown. The maps have been constructed simply by using the 30 and $50 \mathrm{~m}$ isolines of the modern bathymetry (and assuming no or negligible isostatic rebound). Gray circles with numbers indicate location of cores for which records are presented in Fig. 15 (04: BP99-04/7; 38: BP00-38/2, etc.). Black arrows and triangles indicate pathways of terrigenous input by rivers and coastal errosion, respectively. The main depocenter is marked as hatched area.

scale only about $70 \%$ of the riverine suspended matter is trapped in the marginal filter during late Holocene times. This number is significantly lower than that based on modern direct measurements of suspended matter in the estuaries ( $>90 \%$; Lisitzin, 1995; see Fig. 1). When looking at the high sedimentation rates in the southern to southeastern Kara Sea (Fig. 17) where dominantly fine-grained, siliciclastic sediments with elevated organic carbon contents were deposited and which are interpreted as river-derived material (Fig. 8; Stein and Fahl, 2003a; Stein et al. 2003a), it is very probable that significant amount of riverine suspended matter have by-passed the marginal filter zone during the late Holocene at least on a geological time scale.

For several reasons, the budget numbers discussed above still have to be taken as first approximation. For coastal erosion input, the published value of $109 \times 10^{6} \mathrm{tyr}^{-1}$ has been used by Stein and Fahl (2003a) (Table 1; Rachold et al., 2003 based on Romankevich and Vetrov, 2001). According to unpublished first results from ongoing studies on coastal erosion in the Kara Sea, this value probably seems to be too high by a factor of 2-3 (A. Vasiliev, pers. comm., 2003). We also lack on more quantitative data of 
Table 3

Average Holocene (0-11 Cal. kyr BP) values for linear sedimentation rate (LSR), dry density (DD), accumulation rates of total sediment (TS AccR), and budget of total sediment (TS Budget)

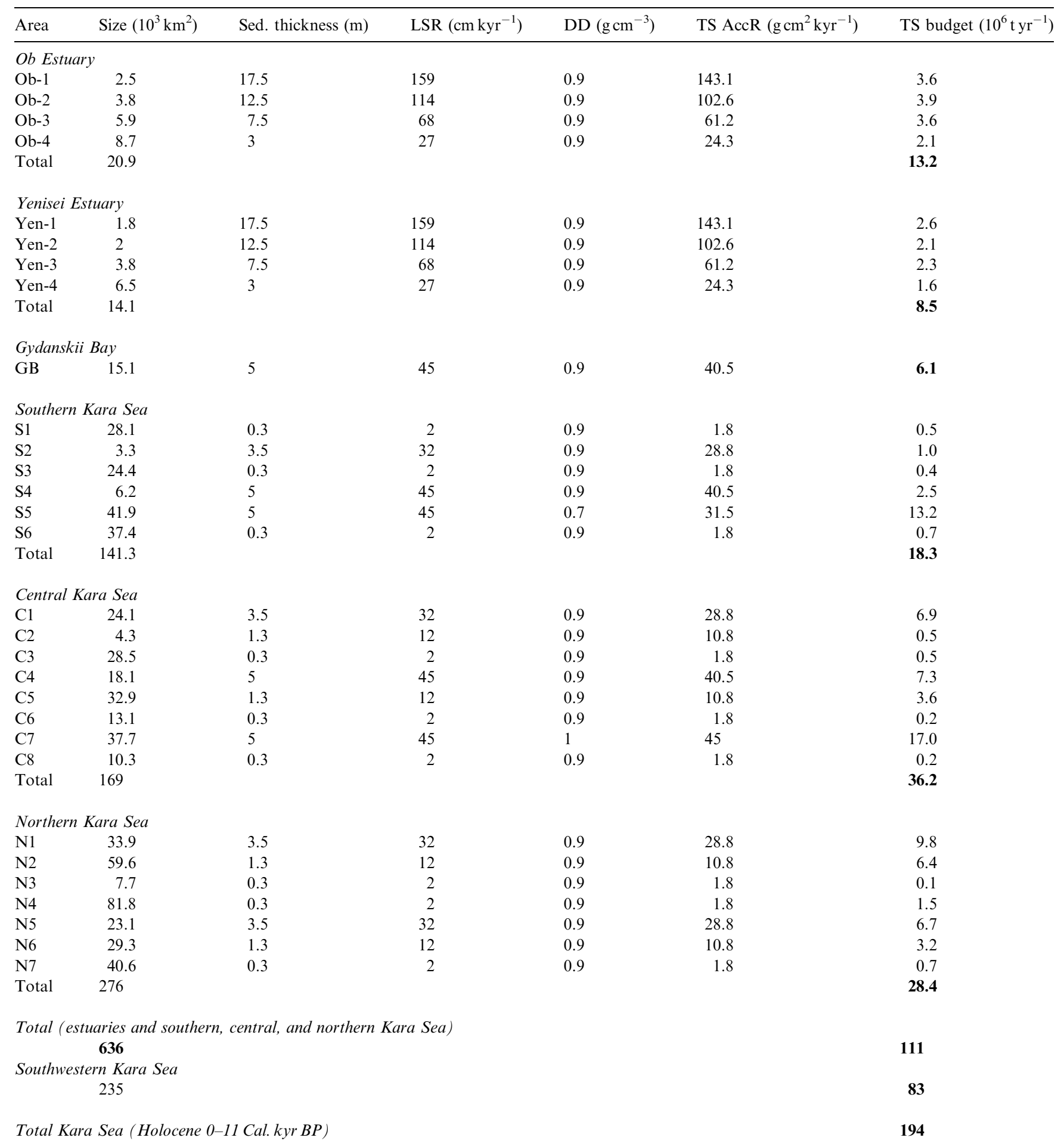

For area code see Fig. 17 (for subareas Ob-1 to Ob-4 and Yen-1 to Yen-4 see Dittmers et al., 2003). Further details and references are given in the text and in Stein and Fahl (2003a).

sediment input from the Barents Sea via Atlantic water inflow as well as from Franz Josef Land, which is assumed from the organic carbon distribution in surface sediments (see Fig. 8). Based on published net inflow values of water masses from the Barents Sea (Pavlov and Pfirman, 1995) and data on suspended matter in these 


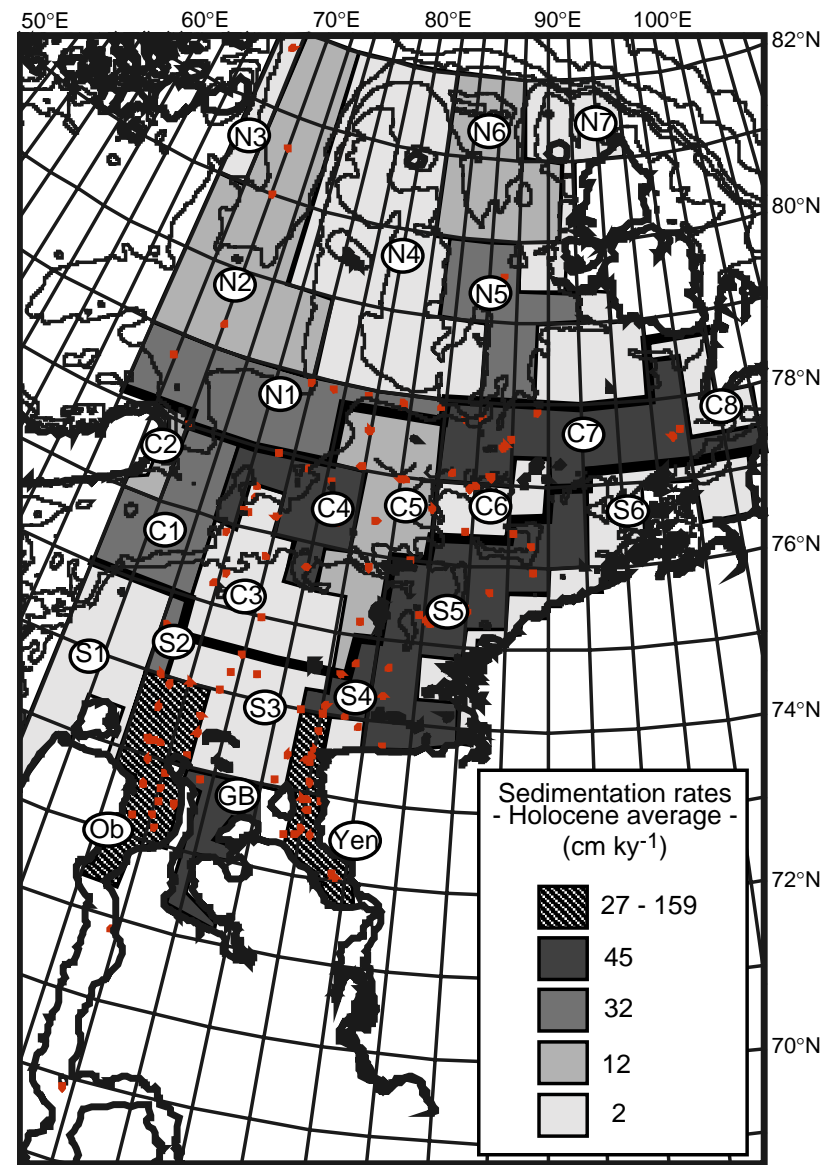

Fig. 17. Distribution map of average Holocene linear sedimentation rates of the Kara Sea (for references see text). The whole area has been divided into four main domains: (1) the marginal filter zone with the $\mathrm{Ob}$ and Yenisei estuaries and Gydanskii Bay; (2) the southern Kara Sea with subareas S1-S6; (3) the central Kara Sea with subareas C1C8; and (4) the Northern Kara Sea with subareas N1-N7 (see Table 3 for area sizes and data).

water masses (Medvedev and Potekhina, 1986), for example, a suspended matter input of 18-33 (max. $88) \times 10^{6} \mathrm{tyr}^{-1}$ is possible (Table 1 ). Whereas the net inflow values are based on long-term measurements over some decades (Pavlov and Pfirman, 1995), the measurements of suspended matter were performed during one expedition in June-September 1982 (Medvedev and Potekhina, 1986). How representative are these measurements? How much of the suspended matter is really accumulating in the Kara Sea, and how much is bypassing into the Arctic Ocean? How important are events of maximum net inflow from the Barents Sea for the sediment budget of the Kara Sea on a geological time scale? Taken a reduced coastal erosion value by $50 \%$ (i.e., about $55 \times 10^{6} \mathrm{tyr}^{-1}$ ), a riverine input of about $40 \times 10^{6} \mathrm{tyr}^{-1}$, and a high value for the ocean current input from the Barents Sea $\left(33-88 \times 10^{6} \mathrm{tyr}^{-1}\right)$, the total sediment input into the Kara Sea could reach about $130-180 \times 10^{6} \mathrm{t} \mathrm{yr}^{-1}$ (Table 1), i.e., a value similar to that used by Stein and Fahl (2003a) (see above). From these uncertainties and open questions in the budget calculations of total sediment (as well as terrigenous particulate organic carbon; see Table 1 and Stein and Fahl, 2003a) it is obvious that future research is needed to prove these preliminary estimates.

\subsection{MS: a proxy for short-term variability in Yenisei discharge and climate?}

As outlined above, a major source of the suspended matter of the Yenisei River are the widespread Triassic plateau basalts and tuff deposits of the Putoran Massif, characterized by high MS values. Thus, the Yeniseiinfluenced surface sediments have very high MS values. Based on this fact, the determination of changes in MS values in a well-dated sediment core from the Yenisei Estuary might be used as proxy for Yenisei discharge and its climate-related variability through time. For this purpose, we have chosen Core BP99-04/7 situated in the northern area of the Yenisei Estuary (Fig. 7).

To test whether MS can be used as a proxy for paleoclimatic conditions of the hinterland and paleoriver discharge, a short sediment core from the central part of the marginal filter characterized by maximum sedimentation rates (Core BP99-31/5; see Fig. 7 for location) has been sampled continuously in $1 \mathrm{~cm}$ slices for MS measurements. Based on Cs-137 dating technique, mean sedimentation rates of recent sediments are as high as $0.3-0.5 \mathrm{~cm} \mathrm{yr}^{-1}$ in this part of the Yenisei Estuary (Stepanets et al., 1999, 2001). Using this dating approach, the short sediment core represents the last about $60-70 \mathrm{yr}$, and one single sample represents about 2-3 yr. The obtained MS record of Core BP99-31/5 is compared with direct Yenisei discharge measurements (Meade et al., 2000; Semiletov et al., 2000) as well as the NAO index record (Hurrell, 1995; Dickson et al., 2000; Peterson et al., 2002). As indicated in Fig. 18, most of the intervals with high MS values seem to correlate with maximum discharge rate and positive NAO Index phases.

Based on these results, we suggest to use the variability of MS values in the sedimentary record of Core BP99-04/7 as a proxy for the Holocene variability in Yenisei River discharge and climatic conditions of the hinterland. At this core location, sediment input by other processes (e.g., coastal erosion and sea ice) is insignificant, except for the Early Holocene when sediment input by coastal erosion due to the lowered sea level may have influenced the deposition at site BP99-04/7 (Stein et al., 2003a). When using this approach for paleoreconstructions, one has to consider that the relation between water discharge and sediment discharge must not have been constant through time, but may have varied as a function of changing weathering conditions in the hinterland. Thus, increased MS 


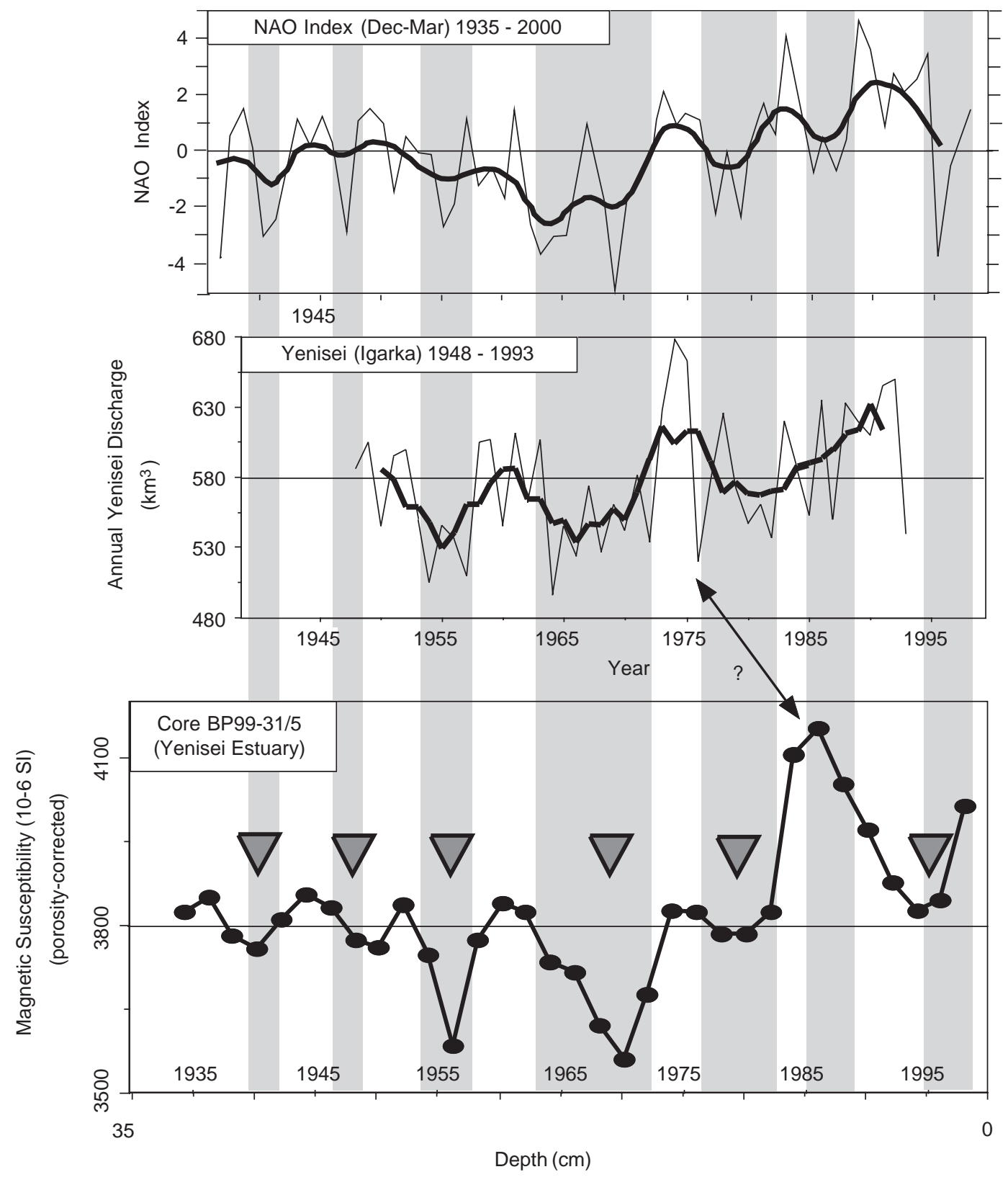

Fig. 18. Porosity-corrected MS values $\left(10^{-6} \mathrm{SI}\right)$ determined in the short sediment core BP99-31/5 located in the central part of the "marginal filter" (see Fig. 7 for location), i.e. the area with maximum modern sediment accumulation. Susceptibility minima are indicated by dark gray triangles. The record is related to the NAO Index (Hurrell, 1995; Dickson et al., 2000) and the annual Yenisei discharge rate measured at Station Igarka (Meade et al., 2000; Semiletov et al., 2000). Vertical gray bars highlight minima in NAO index.

values do not necessarily indicate an increase in absolute river discharge. Instead, the MS is probably more a mixed signal of river discharge and weathering conditions in the hinterland. Since increased (decreased) discharge and more (less) intensive weathering are both related to warmer (cooler) and wetter (dryer) climatic conditions, however, the MS record of Core BP99-04/7 functions as a very useful proxy for paleoclimatic reconstruction.

Looking at the MS record of Core BP99-04/7 for the time interval of the last about $9 \mathrm{Cal} . \mathrm{kyr} \mathrm{BP}$, which represents a high-resolution record of paleoenviron- mental change, a distinct cyclicity is obvious (Fig. 19), supporting short-term Holocene climate variability. Maxima in MS are interpreted as periods of increased discharge of suspended matter from the Putoran Massif. Elevated temperature and precipitation values probably resulted in enhanced weathering and erosion and, thus, increased supply of MS-rich basaltic weathering products. In general, maxima/minima occur at a frequency of about 300-700 yr during the last about 7 Cal. kyr BP. In the time interval between 7 and 9 Cal. kyr BP, even cycles of about $200-250 \mathrm{yr}$ can be resolved. The change from minima to maxima probably happened within less 


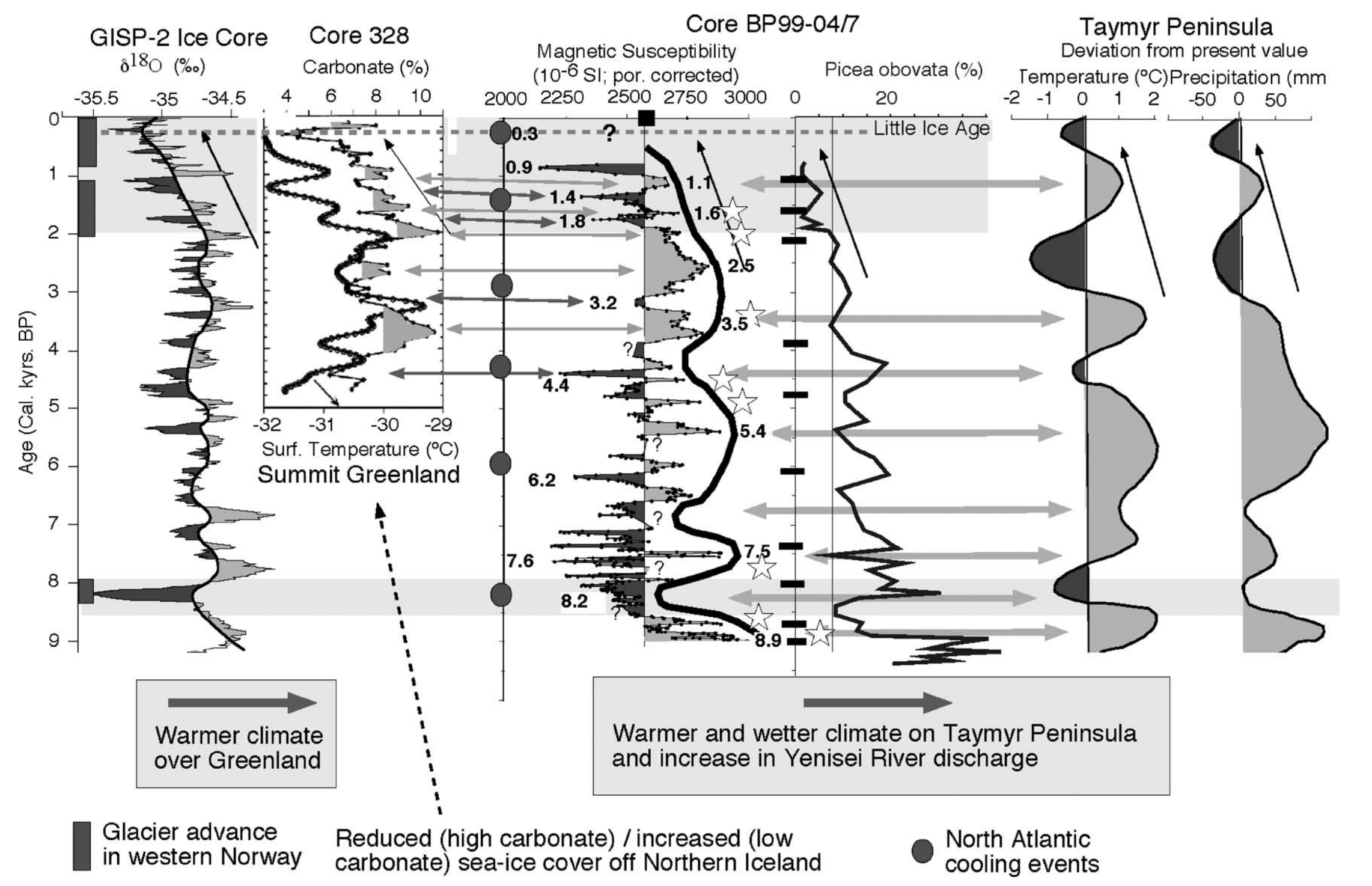

Fig. 19. High-resolution record of porosity-corrected MS ( $\left.10^{-6} \mathrm{SI}\right)$ of Core BP99-04/7 for the last about 9 Cal. kyr BP. The smoothed black curve next to the MS record indicates the lower-frequency variability (trend) of MS maxima. Black square marks susceptibility value determined in surface sediments from this area. Numbers close to the MS minima and maxima are ages in Cal. kyr BP. Question marks in the MS record indicate data gaps between the measured $1 \mathrm{~m}$ core sections. Furthermore, a Picea obovata pollen record (Kraus et al., 2003) and maxima in freshwater diatoms (open stars; Polyakova and Stein, 2003) of Core BP99-04 are shown. The curve from Picea obovata pollen type is generated from the standard pollen percentage diagram with pollen sum = arboreal pollen (AP) + non-arboreal pollen (NAP) without spores (Kraus et al., 2003). The BP99-04/7 MS record is compared with the $\delta^{18}$ O record of the GISP-2 ice core (Grootes et al., 1993) and the deviation of mean annual temperature and precipitation on Taymyr Peninsula based on pollen spectra (Andreev and Klimanov, 2000). The GISP-2 record is a 9-point moving average record. In addition, carbonate maxima and minima in an $\mathrm{AMS}^{14} \mathrm{C}$-dated sediment core off Northern Iceland (B997-328; $65^{\circ} 57.4^{\prime} \mathrm{N}, 21^{\circ} 33.17^{\prime} \mathrm{W}$; water depth $96 \mathrm{~m}$ ), interpreted as signal for reduced and increased sea-ice cover (Andrews et al., 2001), and major cooling events in the North Atlantic (Bond et al., 1997) are indicated. Dark gray vertical bars at the left-hand side of the figure mark periods of major advances of glaciers in western Norway (Nesje et al., 2001). Location of $\mathrm{AMS}^{14} \mathrm{C}$ datings in the BP04/7 record are shown as black horizontal bars. 
than a few decades. The interpretation of the MS record is also supported by freshwater diatoms. Maxima in freshwater diatoms determined in a lower time-resolution record of Core BP99-04/7 (Polyakova and Stein, 2003) and interpreted as river input signal, correspond to MS maxima (Fig. 19, open stars).

In addition to the short-term centennial variability, a lower-frequency millennial variability of minima and maxima in MS seems to be obvious (Fig. 19). On this scale, maxima centered around 8.9, 7.5, 5.4, and 2.53.5 Cal. kyr BP. This cyclicity appears to correlate with the more general climatic curves of air temperature and precipitation on Taymyr Peninsula (Fig. 19) (Andreev and Klimanov, 2000), supporting our interpretation of the MS values in terms of climatic cycles. The major decrease in MS values starting near 2.5 Cal. kyr BP and being more pronounced during the last about $2 \mathrm{Cal}$. kyr BP, may be related to a significant drop in air temperature and mean annual precipitation, as indicated in pollen records from Taymyr Peninsula (Fig. 19) (Andreev and Klimanov, 2000) and from Lama Lake in the Putoran Plateau (Hahne and Melles, 1997; Hubberten et al., 2001) (for location of Lama Lake see Fig. 7). During the last about 2 Cal. kyr BP, most unfavourable climatic conditions and modern vegetation zones in the coastal area and in the hinterland of the Kara Sea region are also reflected in the pollen record of Core BP99-04/7 (Fig. 19). At that time, Picea pollen decreased notably indicating the retreat of the spruce tree line. Additionally, the simultaneous increase of pollen taxa such as Salix, Artemisia, Ranunculaceae, and Thalictrum supports a colder climate as well (Kraus et al., 2003).

In order to prove whether the climate cycles represented by our record is a more local or a regional to global signal, the MS record of Core BP99-04/7 is compared with other climate records (Fig. 19). First of all, the general decrease in MS values and temperature and precipitation on Taymyr Peninsula near $2.5 \mathrm{Cal}$. kyr BP, coincides with a cooling trend over Greenland indicated in the GISP-2 Ice Core (Grootes et al., 1993), as well as an advance of glaciers in western Norway (Nesje et al., 2001). At the same time, the sea-ice cover off Northern Iceland increased as suggested from decreasing carbonate contents used as proxy for primary production and sea-ice cover (Andrews et al., 2001). A large number of MS minima and maxima on the centennial as well as millennial scale can be correlated with the Greenland ice core as well as the sea-ice record off Northern Iceland. Furthermore, major North Atlantic cooling events with peaks near 1.4, 2.8, 4.2, 5.9, and 8.1 Cal.kyr BP (Bond et al., 1997) seem to correlate with minima of MS values (Fig. 19). Also the prominent, widespread 8.2 Cal. kyr BP cooling event present in the Greenland ice core record as well as the glacier record in Norway (Fig. 19) and described in a large number proxy records from the tropics to the north polar regions (Alley et al., 1997 and further references therein), is reflected in the MS record of Core BP99-04/7, indicating a minimum in peak values.

Based on these comparisons, our record on centennial to millennial cyclicity of Siberian climate and river discharge seems to correlate with other climate records and, thus, seems to be of regional (to global) significance. This centennial to millennial variability may reflect natural cyclic climate variations which have to be seen in context with the interannual and interdecadal environmental changes recorded in the High Northern Latitudes over the last decades, such as, for example, the NAO/AO pattern. Positive NAO/AO phases bringing warm and wet air to the Russian Arctic and causing increased surface temperatures, precipitation, and weathering, may have been the trigger for increased riverine input from the Putoran Massif throughout the Holocene. Changes in solar irradiance as a forcing mechanism for Holocene climate variability is discussed by several authors (e.g. Bond et al., 2001). Our still somewhat speculative hypothesis which is important within the ongoing debate about naturally versus anthropogenically driven future climate change, however, has to be proven by further high-resolution multiproxy Arctic climate records. These additional data are required to test whether our Yenisei MS record is mainly controlled by climate factors (i.e., temperature, precipitation, and weathering) and whether other local factors (e.g., sediment redeposition, depocenter migration, and sediment focusing) can be excluded as controlling processes. Furthermore, time series analyses have to be performed on these high-resolution records.

\section{Conclusions}

- The modern river discharge is clearly reflected in the composition of surface sediments. Changes in clay mineral composition, magnetic susceptibility (MS), total organic carbon content, and abundances of fresh-water diatoms and chlorophycean algae allowed to trace the input of riverine matter into the southern Kara Sea. MS values appear to be a very useful proxy to distinguish between sediment input of the Yenisei and $\mathrm{Ob}$ rivers. Sediments supplied by the Yenisei draining the basalts of the Putoran Massiff have very high MS values whereas the sediments supplied by the river $\mathrm{Ob}$ draining the Siberian lowlands, are characterized by very low MS values.

- The post-glacial to Holocene sediment input has been strongly influenced by sea-level rise and related changes in river discharge and coastal erosion. In the earliest Holocene (10-11 Cal. kyr BP), maximum accumulation rates were recorded in the central Kara Sea. Accumulation rates of total sediment reach very high values of about $150-700 \mathrm{~g} \mathrm{~cm}^{-2} \mathrm{kyr}^{-1}$. At that 
time, the sea level was about $40-50 \mathrm{~m}$ lower than today and large parts of the inner Kara Sea were subaerial. Terrigenous sediments were transported much more to the north, and the main depocenter was situated more toward the central Kara Sea. With increasing sea level, sedimentation in the central Kara Sea became drastically reduced, and the main depocenter shifted towards the south, reaching approximately "modern" condition during the last 6 Cal. kyr BP.

- For the entire Kara Sea, we estimate an average Holocene (0-11 Cal. kyr BP) accumulation of $194 \times 10^{6} \mathrm{tyr}^{-1}$ of total sediment. Based on late Holocene (modern) sediment accumulation in the estuaries, probably $12 \times 10^{6} \mathrm{tyr}^{-1}$ of riverine suspended matter (i.e., about $30 \%$ of the input) may escape the marginal filter on a geological time scale and is transported onto the open Kara Sea shelf, and about $27 \times 10^{6} \mathrm{tyr}^{-1}$ of total sediment may be exported from the Kara Sea. These budget numbers are still preliminary estimates which have to be verified by further quantitative data on coastal erosion input, net inflow and outflow rates of suspended matter via ocean currents as well as data on sediment accumulation in the northern Kara Sea and adjacent continental margin.

- The high-resolution MS record of Core BP99-04/7 obtained from northern Yenisei Estuary, suggests centennial to millennial Holocene variability in Siberian climate and river discharge. Maxima in MS are interpreted as periods of increased discharge of suspended matter from the Putoran Massif under more humid climatic conditions. A major decrease in MS values starting near $2.5 \mathrm{Cal}$ kyr BP and being more pronounced during the last about $2 \mathrm{Cal}$. kyr BP, correlates with a cooling trend over Greenland indicated in the GISP-2 Ice Core, extended sea-ice cover in the North Atlantic, and advances of glaciers in western Norway. The short-term MS variability may reflect natural cyclic climate variations related to changes of the NAO/AO pattern. This hypothesis, however, has to be proven by further high-resolution multi-proxy Arctic climate records.

\section{Acknowledgements}

This paper is a contribution to the European Science Foundation program "Quaternary Environment of the Eurasian North" (QUEEN). Major parts of the investigations have been performed within the joint German-Russian multidisciplinary research project on "Siberian River Run-off (SIRRO)". We thank A. Elverhøi and A. Solheim for constructive suggestions for improvement of the manuscript. Financial support by the German Ministry of Education and Science
(BMBF) (Grant no. 03G0547A) and the Russian Foundation of Basic Research is gratefully ackowledged.

\section{References}

Aagaard, K., Carmack, E.C., 1989. The role of sea ice and other fresh water in the Arctic circulation. Journal of Geophysical Research 94 (C10), 14485-14498.

Alley, R.B., Mayewski, P.A., Sowers, T., Stuiver, M., Taylor, K.C., Clark, P.U., 1997. Holocene climatic instability: a prominent, widespread event $8200 \mathrm{yr}$ ago. Geology 25, 483-486.

Andreev, A.A., Klimanov, V.A., 2000. Quantitative Holocene climatic reconstruction from Arctic Russia. Journal of Paleolimnology 24 $81-91$.

Andrews, J.T., Helgadottir, G., Geirsdottir, A., Jennings, A.E., 2001. Multicentury-scale records of carbonate (hydrographic?) variability on the northern Iceland margin over the last 5000 years. Quaternary Research 56, 199-206.

Bauch, H.A., Kassens, H., Naidina, O.D., Kunz-Pirrung, M., Thiede, J., 2001a. Composition and flux of Holocene sediments on the eastern Laptev Sea shelf, Arctic Siberia. Quaternary Research 55, 344-351.

Bauch, H.A., Mueller-Lupp, T., Taldenkova, E., Spielhagen, R.F., Kassens, H., Grootes, P.M., Thiede, J., Heinemeier, J., Petryashov, V.V., 2001b. Chronology of the Holocene transgression at the North Siberian margin. Global Planetary Change 31, 125-139.

Biscaye, P.E., 1965. Mineralogy and sedimentation of recent deep-sea clays in the Atlantic Ocean and adjacent seas and oceans. Geological Society America Bulletin 76, 803-832.

Bjelvin, T.A., Holm, J.P., 1993. GEOGruppen as, Tromsø, Norway, Report No. 93024.02.

Bond, G., Showers, W., Cheseby, M., Lotti, R., Almasi, P., deMenocal, P., Priore, P., Cullen, H., Hajdas, I., Bonani, G., 1997. A pervasive millennial-scale cycle in North Atlantic Holocene and glacial climates. Science 278, 1257-1266.

Bond, G., Kromer, B., Beer, J., Muscheler, R., Evans, M.N., Showers, W., Hoffmann, S., Lotti-Bond, R., Hajdas, I., Bonani, G., 2001. Persistant solar influence on North Atlantic climate during the Holocene. Science 294, 2130-2136.

Boucsein, B., Knies, J., Stein, R., 2002. Organic matter deposition along the Kara and Laptev Seas continental margin (eastern Arctic Ocean) during last deglaciation and Holocene: evidence from organic-geochemical and petrographical data. Marine Geology $183,67-87$.

Broecker, W.S., 1997. Thermohaline circulation, the achilles heel of our climate system: will man-made $\mathrm{CO}_{2}$ upset the current balance? Science 278, 1582-1588.

Burenkov, V.I., Vasil'kov, A.P., 1995. The influence of runoff from land on the distribution of hydrologic characteristics of the Kara Sea. Oceanology 34 (5), 591-599 (English Translation).

Cremer, H., 1999. Distribution patterns of diatom surface sediment assemblages in the Laptev Sea (Arctic Ocean). Marine Micropaleontology 38, 39-67.

Dethleff, D., Rachold, V., Tintelnot, T., Antonow, M., 2000. Sea-ice transport of riverine particles from the Laptev Sea to Fram Strait based on clay mineral studies. International Journal of Earth Sciences 89, 496-502.

Dickson, R.R., Meincke, J., Malmberg, S., Lee, A.J., 1988. The "Great Salinity Anomaly" in the Northern North Atlantic 1968-1982. Progress in Oceanography 20, 103-151.

Dickson, R.R., Osborn, T.J., Hurrell, J.W., Meincke, J., Blindheim, J., Adlandsvik, B., Vinje, T., Alekseev, G., Maslowski, W., 2000. The 
Arctic Ocean response to the North Atlantic oscillation. Journal of Climate 13, 2671-2696.

Dittmers, K., Niessen, F., Stein, R., 2003. Holocene sediment budget and sedimentary history for the $\mathrm{Ob}$ and Yenisei estuaries. In: Stein, R., Fahl, K., Fütterer, D.K., Galimov, E.M., Stepanets, O.V. (Eds.), Siberian River Run-off in the Kara Sea: Characterisation, Quantification, Variability, and Environmental Significance. Proceedings in Marine Sciences, Vol. 6. Elsevier, Amsterdam, pp. 457-484.

Duzhikov, O.A., Strunin, B.M., 1992. Geological outline of the Norilisk region. In: Duzhikov, O.A., Strunin, B.M. (Eds.), Geology and Metallogeny of Sulfide Deposits. Norilisk region: Moscow, USSR SEG Special Publication, pp. 1-60.

Eicken, H., Kolatschek, J., Freitag, J., Lindemann, F., Kassens, H., Dmitrenko, I., 2000. Identifying a major source area and constraints on entrainment for basin-scale sediment transport by Arctic Sea ice. Geophysical Research Letters 27, 1919-1922.

Fahl, K., Stein, R., 1997. Modern organic-carbon-deposition in the Laptev Sea and the adjacent continental slope: surface-water productivity vs. terrigenous input. Organic Geochemistry 26, 379-390.

Fahl, K., Stein, R., 1999. Biomarkers as organic-carbon-source and environmental indicators in the Late Quaternary Arctic Ocean: "Problems and Perspectives". Marine Chemistry 63, 293-309.

Fahl, K., Stein, R., Gaye-Haake, B., Gebhardt, C., Kodina, L.A., Unger, D., Ittekkot, V., 2003. Biomarkers in surface sediments from the $\mathrm{Ob}$ and Yenisei estuaries and southern Kara Sea: evidence for particulate organic carbon sources, pathways, and degradation. In: Stein, R., Fahl, K., Fütterer, D.K., Galimov, E.M., Stepanets, O.V. (Eds.), Siberian River Run-off in the Kara Sea: Characterisation, Quantification, Variability, and Environmental Significance, Proceedings in Marine Sciences, Vol. 6. Elsevier, Amsterdam, pp. 329-348.

Fairbanks, R.G., 1989. A 17,000-year glacio eustatic sea level record: influence of glacial melting rates on the Younger Dryas event and deep-ocean circulation. Nature 342, 637-642.

Fernandes, M.B., Sicre, M.A., 2000. The importance of terrestrial organic carbon inputs on Kara Sea shelves as revealed by $n$-alkanes, $\mathrm{OC}$ and $\delta^{13} \mathrm{C}$ values. Organic Geochemistry 31, 363-374.

Gordeev, V.V., Martin, J.M., Sidorov, I.S., Sidorova, M.V., 1996. A reassessment of the Eurasian river input of water, sediment, major elements, and nutrients to the Arctic Ocean. American Journal of Sciences 296, 664-691.

Grootes, P.M., Stuiver, M., White, J.W., Johnson, S., Jouzel, J., 1993. Comparison of oxygen isotope records from the GISP2 and GRIP Greenland ice cores. Nature 366, 552-554.

Gurevich, V.I., 1995. Recent sedimentogenesis and environment on the Arctic shelf of Western Eurasia. Norsk Polarinstitutt Meddelelser NR 131, Oslo, pp. 1-92.

Hahne, J., Melles, M., 1997. Late- and post-glacial vegetation and climate history of the south-western Taymyr Peninsula, central Siberia, as revealed by pollen analysis of a core from Lama Lake. Vegetation History and Archaeobotany 6, 1-8.

Harms, I.H., Karcher, M.J., Dethleff, D., 2000. Modelling Siberian river runoff-implications for contaminant transport in the Arctic Ocean. Journal of Marine Systems 27, 95-115.

Herlihy, F.A., 1996. A marine sedimentary record of the last glacial cycle in the Franz Victoria and St. Anna Troughs, Northern Barents and Kara Seas, Russia. Unpublished M.S. Thesis, Columbus, Ohio State University, 196pp.

Holmes, R.M., McClelland, J.W., Peterson, B.J., Shiklomanov, A.I., Zhulidov, A.V., Gordeev, V.V., Bobrovitskaya, N., 2002. A circumpolar perspective on fluvial sediment flux to the Arctic Ocean. Global Biogeochemical Cycles, 16/4: 10.1029/ 2002GB001920.
Hubberten, H.-W., Andreev, A., Kuhnke, T., Melles, M., Siegert, C., 2001. The Late Quaternary climatic and environmental history of the Taymyr Peninsula, northern Central Siberia with special emphasis on the last 10,000 years. Terra Nostra 3, 100-104.

Hurrell, J.W., 1995. Decadal trends in the North Atlantic oscillation: regional temperatures and precipitation. Science 269, 676-679.

Kraus, M., Matthiessen, J., Stein, R., 2003. A high-resolution Holocene marine pollen record from the northern Yenisei Estuary (southeastern Kara Sea) and paleoenvironmental implications. In: Stein, R., Fahl, K., Fütterer, D.K., Galimov, E.M., Stepanets, O.V. (Eds.), Siberian River Run-off in the Kara Sea: Characterisation, Quantification, Variability, and Environmental Significance, Proceedings in Marine Sciences, Vol. 6. Elsevier, Amsterdam, pp. 435-456.

Krishnamurthy, R.V., Machavaram, M., Baskaran, M., Brooks, J.M., Champs, M.A., 2001. Organic carbon flow in the Ob, Yenisei rivers and Kara Sea of the Arctic Region. Marine Pollution Bulletin 42, 726-732.

Levitan, M.A., Khusid, T.A., Kuznetsov, V.M., Politova, N.V., Pavlova, G.A., 1995. Sequence types of upper quaternary deposits of the Kara Sea. Oceanology 34, 710-721.

Lisitzin, A.P., 1995. The marginal filter of the ocean. Oceanology 34 (5), 671-682.

Lisitzin, A.P., Vinogradov, M.E., 1995. International high-latitude expedition in the Kara Sea (the 49th cruise of the R/V Dmitriy Mendeleev). Oceanology 34 (5), 583-590.

Lubinski, D.J., Polyak, L., Forman, S.L., 2001. Freshwater and Atlantic water inflows to thedeep northern Barents and Kara seas since ca $13{ }^{14} \mathrm{C}$ ka: foraminifera and stable isotopes. Quaternary Science Review 20, 1851-1879.

Mangerud, J., Gulliksen, S., 1975. Apparent radiocarbon ages of recent marine shells from Norway, Spitsbergen, and Arctic Canada. Quaternary Research 5, 273-296.

Mangerud, J., Astakhov, V., Svendsen, J.I., 2002. The extent of the Barents-Kara ice sheet during the Last Glacial maximum. Quaternary Science Review 21, 111-119.

Matthiessen, J., Stepanets, O.V. (Eds.), 1998. Scientific cruise report of the Kara Sea expedition of RV "Akademik Boris Petrov" in 1997. Reports on Polar Research 266, 102pp.

Matthiessen, J., Stepanets, O.V., Stein, R., Fütterer, D.K., Galimov, E.M. (Eds.), 1999. The Kara Sea Expedition of RV "Akademik Boris Petrov" in 1997: First Results of a joint Russian-German Pilot Study. Reports on Polar Research 300, 239pp.

Matthiessen, J., Kunz-Pirrung, M., Mudie, P.J., 2000. Freshwater chlorophycean algae from the Beaufort, Laptev and Kara Seas (Arctic Ocean) as indicators of river runoff. International Journal of Earth Sciences 89 (3), 470-485.

Meade, R.H., Bobrovitskaya, N.N., Babkin, V.I., 2000. Suspendedsediment and fresh-water discharges in the $\mathrm{Ob}$ and Yenisei rivers, 1960-1988. International Journal of Earth Sciences 89, 578-591.

Medvedev, V.S., Potekhina, Ye.M., 1986. Quantitative distribution and dynamics of suspended matter in the southeastern Barents Sea. Oceanology 26, 481-485.

Milliman, J.D., 1981. Transfer of river-born particulate material to the oceans. In: United Nations, Proceedings of Review Workshop "River Inputs to Ocean systems", Rome, Italy, March 26-30, 1979, pp. $5-12$.

Naidina, O.D., Bauch, H.A., 1999. Distribution of pollen and spores in surface sediments of the Laptev Sea. In: Kassens, H., Bauch, H., Dmitrenko, I., Eicken, H., Hubberten, H.W., Melles, M., Thiede, J., Timokhov, L. (Eds.), Land-Ocean Systems in the Siberian: Dynamics and History. Springer, Berlin, pp. 577-585.

Nesje, A., Matthews, J.A., Dahl, S.O., Berrisford, M.S., Andersson, C., 2001. Holocene glacier fluctuations of Flatebreen and winter-precipitation changes in the Jostedalsbreen region, western 
Norway, based on glaciolacustrine sediment records. The Holocene $11,267-280$.

Niessen, F., Dittmers, K., 2002. Geochirp and Elac sediment echograph profiling. Reports on Polar and Marine Research 419, 64-73.

Niessen, F., Weiel, D., 1996. Distribution of magnetic susceptibility on the Eurasian shelf and continental slope-implications for source area of magnetic minerals. Reports on Polar Research 212, $81-88$.

Niessen, F., Jarrard, R.D., Bücker, C., 1998. Log-based physical properties of the CRP-1 core, Ross Sea, Antarctica. Terra Antarctica 5, 299-310.

Nürnberg, D., Wollenburg, I., Dethleff, D., Eicken, H., Kassens, H., Letzig, T., Reimnitz, E., Thiede, J., 1994. Sediments in Arctic Sea ice - implications for entrainment, transport and release. Marine Geology 119, 185-214.

Pavlov, V.K., Pfirman, S.L., 1995. Hydrographic structure and variability of the Kara Sea: implications for pollutant distribution. Deep-Sea Research II 42, 1369-1390.

Peterson, B.J., Holmes, R.M., McClelland, J.W., Vorosmarty, C.J., Lammers, R.B., Shiklomanov, A.I., Shiklomanov, I.A., Rahmstorf, S., 2002. Increasing river discharge to the Arctic Ocean. Science 298, 2171-2173.

Pfirman, S.L., Lange, M.A., Wollenburg, I., Schlosser, P., 1990. Sea ice characteristics and the role of sediment inclusions in deep-sea deposition: Arctic-Antarctic comparisons. In: Bleil, U., Thiede, J. (Eds.), Geological history of the Polar Oceans: Arctic versus Antarctic. Kluwer Academic Publishers, Dordrecht, pp. 187-211.

Polyak, L., Forman, S.L., Herlihy, F.A., Ivanov, G., Krinitsky, P., 1997. Late Weichselian deglacial history of the Svyataya (Saint) Anna Trough, northern Kara Sea, Arctic Russia. Marine Geology 143, 169-187.

Polyak, L., Gataullin, V., Gainanov, V., Gladysh, V., Goremykin, Y., 2002a. Kara Sea expedition yields insight into of LGM ice sheet. EOS 83, 525-529.

Polyak, L., Levitan, M., Khusid, T., Merklin, L., Mukhina, V., 2002b. Variations in the influence of riverine discharge on the Kara Sea during the last deglaciation and the Holocene. Global Planetary Change 32, 291-309.

Polyakova, Ye., 2003. Diatom assemblages in surface sediments of the Kara Sea (Siberian Arctic) and their relationship to oceanological conditions. In: Stein, R., Fahl, K., Fütterer, D.K., Galimov, E.M., Stepanets, O.V. (Eds.), Siberian River Run-off in the Kara Sea: Characterisation, Quantification, Variability, and Environmental Significance, Proceedings in Marine Sciences, Vol. 6. Elsevier, Amsterdam, pp. 375-400.

Polyakova, Ye., Stein, R., 2003. Holocene paleoenvironmental implications of diatom and organic carbon records from the Southeastern Kara Sea (Siberian Margin). Quaternary Research, in press.

Rachold, V., Eicken, H., Gordeev, V.V., Grigoriev, M.N., Hubberten, H.-W., Lisitzin, A.P., Shevchenko, V.P., Schirmeister, L., 2003. Modern terrigenous organic carbon input to the Arctic Ocean. In: Stein, R., Macdonald, R.W. (Eds.), The Arctic Ocean Organic Carbon Cycle: Present and Past. Springer, Berlin, pp. 33-56.

Rochon, A., de Vernal, A., Turon, J.-L., Matthiessen, J., Head, M.J., 1999. Distribution of Dinoflagellate Cysts in Surface Sediments from the North Atlantic Ocean and Adjacent Basins and Quantitative Reconstruction of Sea-surface Parameters. American Association Stratigraphy Palynology Contribution Series 35, 146pp. Dallas, TX.

Romankevich, E.A., Vetrov, A.A., 2001. Cycle of Carbon in the Russian Arctic Seas. Nauka, Moscow, 302pp. (in Russian).

Romankevich, E.A., Korneeva, G.A., Shevchenko, V.P., Gordeev, V.Yu., Belyaev, N.A., 2000. Suspended organic matter in the Barents Sea. Oceanology 40, 208-216.
Schoster, F., Levitan, M.A., 2003. Scientific cruise report of the joint Russian-German Kara-Sea expedition of RV "Akademik Boris Petrov" in 2002. Reports on Polar and Marine Research 450, 109pp.

Schultheiss, P.J., McPhail, S.D., 1989. An automated p-wave logger for recording fine scale compressional wave velocity in sediments. In: Ruddiman, W., Sarnthein, M., et al. (Eds.), Proceedings of the ODP Initial Reports 108, pp. 407-413.

Schultheiss, P.J., Mienert, J., 1987. Whole-core p-wave velocity and gamma-ray attenuation logs from Leg 108 (sites 657 through 668). In: Ruddiman, W., Sarnthein, M., et al. (Eds.), Proceedings of the ODP Initial Reports 108, pp. 1015-1017.

Semiletov, I.P., Savelieva, N.I., Weller, G.E., Pipko, I.I., Pugach, S.P., Gukov, A.Yu., Vasilevskaya, L.N., 2000. The dispersion of Siberian river flows into coastal waters: meteorological, hydrological and hydrochemical aspects. In: Lewis, E.L. (Ed.), The Freshwater Budget of the Arctic Ocean. Kluwer Academic Publishers, Dordrecht, pp. 323-366.

Serreze, M.C., Walsh, J.E., Chapin, F.S., Osterkamp, T., Dyurgerov, M., et al., 2000. Observational evidence of recent changes in the northern high-latitude environment. Climatic Change 46, 159-207.

Shiklomanov, I.A., Skakalsky, B.G., 1994. Studying water, sediment and contaminant run-off of Siberian Rivers. Modern status and prospects. Arctic Research US 8, 295-306.

Stein, R. (Ed.), 1998. Arctic Paleo-River Discharge (APARD) - a new research programme of the Arctic Ocean Science Board (AOSB). Reports on Polar Research 279, 127pp.

Stein, R. (Ed.), 2000. Circum Arctic River discharge and its geological record. International Journal of Earth Sciences 89, 447-616.

Stein, R., 2001. Lithostratigraphy of gravity cores and correlation with sediment echograph profiles ("Akademik Boris Petrov" Kara Sea expeditions 1999 and 2000). Reports on Polar and Marine Research 393, 120-140.

Stein, R., Fahl, K., 2000. Holocene Accumulation of Organic Carbon at the Laptev Sea Continental Margin (Arctic Ocean): sources, pathways, and sinks. Geo-Marine Letters 20, 27-36.

Stein, R., Fahl, K., 2003a. The Kara Sea: distribution, sources, variability and burial of organic carbon. In: Stein, R., Macdonald, R.W. (Eds.), The Organic Carbon Cycle in the Arctic Ocean. Springer, Berlin, pp. 237-266.

Stein, R., Fahl, K., 2003b. The Laptev Sea: distribution, sources, variability and burial of organic carbon. In: Stein, R., Macdonald, R.W. (Eds.), The Organic Carbon Cycle in the Arctic Ocean. Springer, Berlin, pp. 213-237.

Stein, R., Macdonald, R.W., 2003. Organic carbon budget: Arctic Ocean vs. global ocean. In: Stein, R., Macdonald, R.W. (Eds.), The Organic Carbon Cycle in the Arctic Ocean. Springer, Berlin, pp. 315-322.

Stein, R., Stepanets, O. (Eds.), 2000. Scientific cruise report of the joint Russian-German Kara-Sea expedition of RV "Akademik Boris Petrov" in 1999. Reports on Polar Research 360, 141pp.

Stein, R., Stepanets, O. (Eds.), 2001. The German-Russian project on Siberian River Run-Off (SIRRO): scientific cruise report of the Kara Sea expedition "SIRRO 2000" of RV "Akademik Boris Petrov" and first results. Reports on Polar and Marine Research 393, 287pp.

Stein, R., Stepanets, O. (Eds.), 2002. Scientific Cruise report of the Kara Sea expedition 2001 of RV "Akademik Boris Petrov": the German-Russian project on Siberian River Run-Off (SIRRO) and the EU-Project "ESTABLISH". Reports on Polar and Marine Research 419, 278pp.

Stein, R., Boucsein, B., Hefter, J., Kraus, M., Lau, N., Schoster, F., Simstich, J., Weiel, D., 2000. Marine geology. In: Stein, R., Stepanets, O.V. (Eds.), Scientific Cruise Report of the Joint Russian-German Kara-Sea Expedition of RV "Akademik Boris Petrov" in 1999. Reports on Polar Research 360, pp. 49-69. 
Stein, R., Boucsein, B., Fahl, K., Garcia de Oteyza, T., Knies, J., Niessen, F., 2001. Accumulation of particulate organic carbon at the Eurasian continental margin during Late Quaternary times: controlling mechanisms and paleoenvironmental significance. Global Planetary Change 31 (1-4), 87-102.

Stein, R., Niessen, F., Dittmers, K., Levitan, M., Schoster, F., Simstich, J., Steinke, T., Stepanets, O.V., 2002. Siberian river runoff and Late Quaternary glaciation in the Southern Kara Sea: preliminary results. Polar Research 21, 315-322.

Stein, R., Fahl, K., Dittmers, K., Niessen, F., Stepanets, O.V., $2003 \mathrm{a}$. Holocene siliciclastic and organic carbon fluxes in the $\mathrm{Ob}$ and Yenisei estuaries and the adjacent inner Kara Sea: quantification, variability, and paleoenvironmental implications. In: Stein, R., Fahl, K., Fütterer, D.K., Galimov, E.M., Stepanets, O.V. (Eds.), Siberian River Run-off in the Kara Sea: Characterisation, Quantification, Variability, and Environmental Significance, Proceedings in Marine Sciences, Vol. 6. Elsevier, Amsterdam, pp. 401-434.

Stein, R., Fahl, K., Fütterer, D.K., Galimov, E.M., Stepanets, O.V. (Eds.), 2003b. Siberian River Run-off in the Kara Sea: Characterisation, Quantification, Variability, and Environmental Significance, Proceedings in Marine Sciences, Vol. 6. Elsevier, Amsterdam, 484pp.

Steinke, T., 2002. Rekonstruktion spätquartärer Paläo-Umweltbedingungen in der Kara-See anhand sedimentologischer und mineralogischer Untersuchungen. Unpublished Master Thesis, Bremen University, 98pp.

Stepanets, O.V., Borisov, A.P., Soloveva, G.Yu., 1999 Distribution of anthropogenic radionuclides in the estuaries of $\mathrm{Ob}$ and Yenisei rivers and adjacent Kara Sea: Reports on Polar Research 300, pp. $132-141$.

Stepanets, O.V., Borisov, A.P., Ligaev, A.N., Galimov, E.M., 2001. Estimation of the sedimentation rate for modern sediments of the Kara Sea: evidence from radioactive tracers. Geochemistry International 39, 752-761.

Stockmarr, J., 1971. Tablets with spores used in absolute pollen analysis. Pollen Spores 13, 615-621.
Stuiver, M., Reimer, P.J., Bard, E., Beck, J.W., Burr, G.S., Hughen, K.A., Cromer, B., McCormic, G., van der Plicht, J., Spurk, M., 1998. INTCAL 98 radiocarbon age calibration $24,000-0$ cal BP. Radiocarbon 40, 1041-1083.

Svendsen, J.I., Astakhov, V.I., Bolshiyanov, D.Y., Demidov, I., Dowdeswell, J.A., Gautallin, V., Hjort, Ch., Hubberten, H.W., Larsen, E., Mangerud, J., Melles, M., Möller, P., Saarnisto, M., Siegert, M.J., 1999. Maximum extent of the Eurasian ice sheets in the Barents and Kara Sea region during the Weichselian. Boreas 28, 234-242.

Telang, S.A., Pocklington, R., Naidu, A.S., Romankevich, A.E., Gitelson, I.I., Gladdyshev, M.I., 1991. Carbon and mineral transport in major North American, Russian Arctic, and Siberian rivers: the St. Lawrence, the Mackenzie, the Yukon, the Arctic Alaskan rivers, the Arctic Basin rivers in the Soviet Union, and the Yenisei. In: Degens, E.T., Kempe, S, Richey, J.E. (Eds.), Biogeochemistry of Major World Rivers. Wiley, Chichester, New York, Brisbane, Toronto, Singapore, Scope 42, 75-104.

Thompson, D.W.J., Wallace, J.M., 1998. The Arctic oscillation signature in the wintertime geopotential height and temperature fields. Geophysical Research Letters 25, 1297-1300.

Thompson, R., Oldfield, F., 1986. Environmental Magnetism. Allen and Unwin, Boston.

Velichko, A.A., Dolukhanov, P.M., Rutter, N.W., Catto, N.R. (Eds.), 1997. Quaternary of northern Eurasia: Late Pleistocene and Holocene landscapes, stratigraphy and environments. Quaternary International 41/42, 1991pp.

Vetrov, A.A., Romankevich, E.A., 2003. The Barents Sea: distribution, sources, variability and burial of organic carbon. In: Stein, R., Macdonald, R.W. (Eds.), The Organic Carbon Cycle in the Arctic Ocean. Springer, Berlin, pp. 266-279.

Weaver, P.P.E., Schultheiss, P.J., 1990. Current methods for obtaining, logging and splitting marine sediment cores. Marine Geophysical Research 12, 85-100.

Weber, E.M., Niessen, F., Kuhn, G., Wiedicke, M., 1997. Calibration and application of marine sedimentary physical properties using a multi-sensor core logger. Marine Geology 136, 151-172. 